\title{
Chemical and biological characteristics of propolis from Apis mellifera caucasica from the Ardahan and Erzurum provinces of Turkey: a comparative study
}

\author{
Mehmet Arslan ${ }^{1}$, Yusuf Sevgiler ${ }^{2}$, Celal Güven ${ }^{3}$, Zehra Tuğba Murathan ${ }^{4}$, Nurcan Erbil ${ }^{5}$, \\ Deniz Yıldırım ${ }^{6}$, Mehmet Büyükleyla ${ }^{7}$, Şakire Karadaş ${ }^{8}$, Rima Çelik ${ }^{9}$, and Eyyüp Rencüzoğulları ${ }^{2}$ \\ ${ }^{1}$ Ardahan University Faculty of Health Sciences, Department of Health Management, Ardahan, Turkey \\ ${ }^{2}$ Adryaman University Faculty of Science and Letters, Department of Biology, Adlyaman, Turkey \\ ${ }^{3}$ Niğde Ömer Halisdemir University Faculty of Medicine, Department of Biophysics, Niğde, Turkey \\ ${ }^{4}$ Malatya Turgut Özal University, Battalgazi Vocational School, Battalgazi, Turkey \\ ${ }^{5}$ Ardahan University Faculty of Health Sciences, Department of Nursing, Ardahan, Turkey \\ ${ }^{6}$ Çukurova University Faculty of Ceyhan Engineering, Department of Chemical Engineering, Ceyhan, Turkey \\ ${ }^{7}$ Ardahan University, Ardahan Vocational School of Health Services, Ardahan, Turkey \\ ${ }^{8}$ Kahramanmaraş Sütçü Imam University Faculty of Science and Letters, Department of Biology, Kahramanmaraş, Turkey \\ ${ }^{9}$ Kilis 7 Arallk University Faculty of Science and Letters, Department of Molecular Biology and Genetics, Kilis, Turkey
}

[Received in September 2020; Similarity Check in September 2020; Accepted in March 2021]

\begin{abstract}
The aim of this study was to compare the biological activities of ethanolic propolis extracts of Apis mellifera caucasica obtained from Ardahan and Erzurum provinces of Turkey. Samples were tested for antioxidant, anticytotoxic, anticarcinogenic, antibacterial, and antifungal potentials using different techniques. Propolis samples from the two provinces had different mineral and organic compositions related to their geographical origin. The ferric reducing antioxidant power (FRAP) test showed superiority of Ardahan propolis over the Erzurum. Regardless of origin and the presence of mitomycin $\mathrm{C}$ in the culture medium, propolis enhanced human peripheral lymphocyte viability, which depended on the duration and propolis concentration. Antiperoxidative activity on MCF-7 breast cancer cells was concentrationdependent. Erzurum propolis showed the highest anticarcinogenic activity at the concentrations of $62.5 \mu \mathrm{g} / \mathrm{mL}$ and $125 \mu \mathrm{g} /$ $\mathrm{mL}$, which dropped at higher concentrations. All propolis samples also showed antibacterial activity against the tested human pathogens similar to ampicillin and penicillin controls, except for Pseudomonas aeruginosa. However, they did not exert any antifungal activity against Candida albicans and Yarrowia lipolytica. In conclusion, propolis samples from both provinces showed promising biological activities, but further research should focus on finding the right concentrations for optimal effect and include the cell necrosis pathway to get a better idea of the anticarcinogenic effects.
\end{abstract}

KEY WORDS: anticarcinogen; antimicrobial; biological activity; mineral; mitomycin C; organic composition

Bees produce propolis from beeswax, vegetable balsam, pollens, and resins to strengthen and disinfect their beehives (1), and its biological properties have shown potential for human use from ancient times. Current research has established that its chemical composition and antimicrobial, antioxidant, anti-inflammatory, and anticarcinogenic properties vary from one location to another (2-8), as they stem from plant origin, phenolic compounds, flavonoids and their esters (9-11), climate, season, time of collection, and bee race $(12,13)$. Another important factor to consider is contamination of the beehive location (14).

Spanning over different climatic and geographic regions Turkey has different honeybee races and ecotypes. The Erzurum province accommodates smaller, yellow-coloured

Corresponding author: Yusuf Sevgiler, Adıyaman University Faculty of Science and Letters, Department of Biology, 02040 Adiyaman, Turkey, E-mail: ysevgiler@adiyaman.edu.tr local bee ecotype, too aggressive for keeping, and the more common genotypes Apis mellifera caucasica, A. m. carnica, and $A$. $m$. anatoliaca (15). The last is the most preferred by beekeepers thanks to its wintering ability and honey yield (16). In contrast, the Ardahan and Artvin provinces are $A$. $m$. caucasica reserves, which means that no other bee races are kept and bred there.

Considering that an earlier study singled out antimicrobial activities of propolis from A. m. caucasica in the Erzurum province (17) and that little else is known about the bioactive properties of propolis of A. m. caucasica from its natural reserve (Posof District) in the Ardahan province, we wanted to compare the inorganic and organic composition, and biological activities of propolis samples of this race from the two adjacent, yet climatically different provinces. 


\section{MATERIALS AND METHODS}

\section{Materials}

All chemicals were purchased from Merck KGaA (Darmstadt, Germany) and its subsidiary Sigma-Aldrich (St. Louis, MO, USA) and included the following: certified reference material (CRM) BCR679 for mineral analysis, glucose, vanillic acid, sinapic acid, trans-ferulic acid, naringenin, sucrose, caffeic acid, $p$-coumaric acid, and sorbic acid standards (Sigma-Aldrich); vitamin C, benzoic acid, standard fatty acids CRM47885 (37 Component FAME Mix, Supelco, Bellefonte, PA), and standard fructose (Merck KGaA).

\section{Propolis collection}

All the propolis samples were collected in October 2016, placed in clean plastic pouches, and stored at $-80{ }^{\circ} \mathrm{C}$ until processing. Ardahan propolis samples were obtained from A. $m$. caucasica beehives located in Posof in Ardahan province, and Erzurum propolis samples were obtained from A. m. caucasica beehives located at the apiculture units of the Atatürk University.

\section{Preparation of ethanolic propolis extracts}

To obtain biologically active compounds we used the ethanolic extraction method described elsewhere (18). Briefly, $2 \mathrm{~g}$ of solid propolis was mixed with $100 \mathrm{~mL}$ of $70 \%$ ethanol. The mixture then sonicated in an ultrasonic bath (model 621.08.001, Isolab Laborgeräte $\mathrm{GmbH}$, Eschau, Germany) at $300 \mathrm{~W}$ for $30 \mathrm{~min}$. The solvent was removed in a rotary evaporator (Rotavapor R-210, Büchi Labortechnik AG, Flawil, Switzerland) at 16-17 kPa (160-170 mbar) and $60^{\circ} \mathrm{C}$. Extraction yields were $20.1 \%(396.7 / 1973.6 \mathrm{w} / \mathrm{w})$ and $23.75 \%(486.7 / 2045.2 \mathrm{w} / \mathrm{w})$ for the Ardahan and Erzurum samples, respectively. Dried matter was weighed and dissolved in $70 \%$ ethanol to obtain a $20 \mathrm{mg} / \mathrm{mL}$ solution for further use, except for microbiological analysis (19). In our preliminary experiments, however, this ethanolic extract showed no antimicrobial activity against the tested microorganisms, which is why we used another extraction method to obtain propolis balsam for antimicrobial activity tests, as follows (20): $30 \mathrm{~g}$ of solid propolis was mixed with $300 \mathrm{~mL}$ of $95 \%$ ethanol. The mixture was shaken in a shaker (SI-300, Lab Companion, Daejeon, South Korea) at $37^{\circ} \mathrm{C}$ for $96 \mathrm{~h}$, and the solvent evaporated in a rotary evaporator (RE100-Pro, SciLogex, Rocky Hill, CT, USA).

\section{Determination of minerals in raw propolis}

Because of lower mineral levels in the obtained propolis ethanolic extracts compared to raw samples reported elsewhere (21), we decided to determine the whole mineral content in raw material. Each raw propolis sample was divided in three samples, each analysed in triplicate to ensure statistical comparison. For this purpose, we used microwave-assisted digestion as described by Korn et al. (22) and analysed the samples for $\mathrm{Co}, \mathrm{Se}, \mathrm{Li}, \mathrm{Cd}, \mathrm{As}, \mathrm{Cr}$, $\mathrm{Ni}, \mathrm{Pb}, \mathrm{Cu}, \mathrm{Ca}, \mathrm{Mg}, \mathrm{K}, \mathrm{Mn}, \mathrm{Na}, \mathrm{Zn}, \mathrm{Fe}$, and $\mathrm{Al}$ content with inductively coupled plasma mass spectrometry (ICP-MS; NexION 350X, Perkin Elmer Inc., Waltham, MA, USA). Standard yttrium was also read to ensure the precision of the device (recovery interval was 97.8-119.3\%). Method accuracy was tested with the CRM BCR679 using the same protocol. $\mathrm{Cd}, \mathrm{Cu}$, and $\mathrm{Ni}$ were within the range of $95 \%$ confidence interval $\left(\mathrm{CI}_{95}\right)$, while $\mathrm{Zn}$ was slightly above the $\mathrm{CI}_{95}$ reported for the CRM.

$\mathrm{N}, \mathrm{C}$, and $\mathrm{S}$ content was determined with an elemental analyser (Flash 2000, Thermo Fisher Scientific Inc., Waltham, MA, USA). Approximately $2 \mathrm{mg}$ of raw propolis were digested with oxygen at $950^{\circ} \mathrm{C}$ using helium as mobile phase. The results are given as the percentage of the total mass.

\section{Determination of fatty acids in raw propolis}

Fatty acid content in raw propolis was analysed in a gas chromatograph equipped with a flame ionisation detector (FID) (GC QP2010 Plus, Shimadzu Corp., Kyoto, Japan). Lipid extraction followed the method described by Hara and Radin (23) with a minor modification as follows: $5 \mathrm{~g}$ of raw propolis was homogenised in $6 \mathrm{~mL}$ of $3 / 2(\mathrm{v} / \mathrm{v})$ hexane/isopropanol mixture for $30 \mathrm{~s}$ and the homogenate centrifuged at $4500 \mathrm{~g}$ for $10 \mathrm{~min}$. Methyl ester forms were derivatised according to the method described by Christie (24). Methyl ester derivatives were then injected into the Rx-2330 column (60 m x $0.25 \mathrm{~mm}$ inner diameter, $0.1 \mu \mathrm{m}$ film thickness, Restek Corp., Bellefonte, PA, USA) in split mode at $250{ }^{\circ} \mathrm{C}$ using helium as carrier gas at $113.1 \mathrm{~mL} /$ min. The temperature program of the column was as follows: the initial temperature of $130{ }^{\circ} \mathrm{C}$ was held for $4 \mathrm{~min}$, then increased at $3{ }^{\circ} \mathrm{C} / \mathrm{min}$ to $230{ }^{\circ} \mathrm{C}$ and held for $10 \mathrm{~min}$. The temperature of the FID was $255^{\circ} \mathrm{C}$. Standards were used to determine the retention time of fatty acids. The content of each fatty acid was calculated as the percentage of total peak area obtained from whole fatty acids in a propolis sample.

\section{Determination of vitamin $C$ and carbohydrate content in raw propolis}

Here too we used raw propolis samples because of higher solubility of carbohydrates and vitamin $\mathrm{C}$ in water than in ethanol. $2 \mathrm{~g}$ of raw propolis was vortexed and then sonicated in a $2 \mathrm{~mL}$ of $95 / 05 \mathrm{methanol} /$ water mixture (pH 3.0) for vitamin $\mathrm{C}$ analysis. $50 \mu \mathrm{L}$ of this extract was injected into a high-performance liquid chromatograph (HPLC) (Prominence LC-20A, Shimadzu Corp.) equipped with a C18 ODS3 column $(150 \times 4.6 \mathrm{~mm}, 5 \mu \mathrm{m}$, Inertsil, GL Sciences Inc., Tokyo, Japan). The injection volume, pressure, flow rate in isocratic mode, and temperature were $50 \mu \mathrm{L}, 200 \mathrm{bar}, 1 \mathrm{~mL} / \mathrm{min}$, and $40^{\circ} \mathrm{C}$, respectively. Vitamin $\mathrm{C}$ content was determined with the photo-diode array 
detector (SPD-M20A, Shimadzu Corp.) at $242 \mathrm{~nm}$. The mobile phase was methanol/water mixture $(5 / 95 \mathrm{v} / \mathrm{v}, \mathrm{pH} 3)$. Vitamin $\mathrm{C}$ concentration in propolis was calculated using the standard curve.

For carbohydrate analysis, raw propolis $(5 \mathrm{~g})$ was mixed with $80 \mathrm{~mL}$ of ultra-pure water and then with $20 \mathrm{~mL}$ acetonitrile. Fructose, glucose, and sucrose in this extract were analysed with an HPLC (Prominence LC-20A, Shimadzu Corp.) equipped with an $\mathrm{NH}_{2}$ column $(250 \mathrm{x}$ $4.6 \mathrm{~mm}, 5 \mu \mathrm{m}$, Inertsil, GL Sciences Inc.) and a refractive index detector (RID-20A, Shimadzu Corp.). The mobile phase was acetonitrile/water mixture $(80 / 20 \mathrm{v} / \mathrm{v})$. The injection volume, column pressure, flow rate in isocratic mode, and temperature were $20 \mu \mathrm{L}, 200 \mathrm{bar}, 1.3 \mathrm{~mL} / \mathrm{min}$, and $30{ }^{\circ} \mathrm{C}$, respectively. Standard curves prepared with fructose, glucose, and sucrose were used to calculate the amount of these components in propolis samples.

\section{Determination of alkaloid, organic acid, and flavonoid content in propolis extracts}

Alkaloids, organic acid, and flavonoids were determined in ethanolic propolis extracts with a gas chromatograph (7890, Agilent Technologies Inc., Santa Clara, CA, USA) equipped with a mass spectrometer $(5975 \mathrm{C}$, Agilent Technologies Inc.). Silylation followed the method described by Proestos and Komaitis (25). The injection temperature was $280^{\circ} \mathrm{C}$, split ratio $40: 1$, flow rate $1 \mathrm{~mL} /$ $\mathrm{min}$, and the run time $35 \mathrm{~min}$. The composition of the eluates was matched with the NIST MS Search 2.0 library (National Institute of Standards and Technology, Gaithersburg, MD, USA).

\section{Determination of phenolic acid content in propolis extracts}

Phenolic acid content was analysed in ethanolic propolis extracts with an HPLC (Prominence LC-20A, Shimadzu Corp.) equipped with an ODS-3 column $(250 \mathrm{x} 4.6 \mathrm{~mm}$, $5 \mu \mathrm{m}$, Inertsil, GL Sciences Inc.). The injection volume was $20 \mu \mathrm{L}$, column pressure 200 bar, flow rate in gradient mode $0.7 \mathrm{~mL} / \mathrm{min}$, and temperature $25^{\circ} \mathrm{C}$. Eluent A was a mixture of methanol, water, and acetic acid (10/89/1 v/v/v) and eluent $\mathrm{B}$ a mixture of methanol and acetic acid (99/1 v/v). The gradient program started with $100 \%$ of solvent A to gradually reduce it to $95,80,75,70,60,50,40$, and $0 \%$ at $3,18,30,35,40,55,65$, and $68 \mathrm{~min}$, respectively. Diode array detector (SPD-M20A, Shimadzu Corp.) was used at $226 \mathrm{~nm}$ wavelength for benzoic acid and at $254 \mathrm{~nm}$ wavelength for vanillic acid, sinapic acid, trans-ferulic acid, naringenin, caffeic acid, $p$-coumaric acid, and sorbic acid. Standard curves were prepared to determine their amounts in the samples.

\section{Determination of total phenolic and flavonoid content}

Total phenolic and flavonoid contents were determined spectrophotometrically (S1205, Unico Science, Dayton,
NJ, USA) in $20 \mathrm{mg} / \mathrm{mL}$ propolis extracts through total antioxidant capacity determination based on 2,2-diphenyl1-picrylhydrazyl (DPPH) reducing potential and ferric reducing antioxidant power (FRAP).

For total phenolic content determination, we used the Folin-Ciocalteu method as described elsewhere (26). $0.5 \mathrm{~mL}$ of propolis extract was mixed with $2.5 \mathrm{~mL}$ of $0.2 \mathrm{eq} / \mathrm{L}$ Folin-Ciocalteu's reagent and $2 \mathrm{~mL}$ of $75 \mathrm{~g} / \mathrm{L}$ sodium carbonate, and the mixture was incubated at room temperature for $2 \mathrm{~h}$. The absorbance of the final solution was measured at $760 \mathrm{~nm}$ and converted to mass fraction using the standard graphic prepared with gallic acid (in the range of $0-250 \mathrm{mg} / \mathrm{L}$ ). All the assays were done in triplicate, and the results presented as $\mathrm{mg}$ of gallic acid equivalent (GAE) per gram of propolis.

Total flavonoid content was spectrophotometrically determined following the methods described elsewhere (27, 28). $0.5 \mathrm{~mL}$ of the propolis extract was incubated with $1.5 \mathrm{~mL}$ of $95 \%$ ethanol, $0.1 \mathrm{~mL}$ of $10 \%$ of $\mathrm{AlCl}_{3}, 0.1 \mathrm{~mL}$ of $1 \mathrm{~mol} / \mathrm{L}$ potassium acetate, and $2.8 \mathrm{~mL}$ of distilled water at room temperature for $30 \mathrm{~min}$. Absorbance was measured at $415 \mathrm{~nm}$ and converted to mass fraction using the standard graphic prepared with quercetin (in the range of $0-700 \mathrm{mg} / \mathrm{L}$ ). Data were presented as $\mu \mathrm{g}$ of quercetin equivalent $(\mathrm{QE})$ per gram of propolis.

\section{Total antioxidant capacity analysis}

Total antioxidant capacity of ethanolic propolis extracts was determined with two methods: DPPH and FRAP. For the DPPH determination we mixed $1.5 \mathrm{~mL}$ of extract with $1.5 \mathrm{~mL}$ of $0.1 \mathrm{mmol} / \mathrm{L} \mathrm{DPPH}$ and incubated the mixture in a dark place at room temperature for $50 \mathrm{~min}$. Absorbance was measured at $517 \mathrm{~nm}$ and converted to concentration expressed as percentage of control using the formula provided by Molyneux (29).

For the FRAP analysis we mixed $100 \mu \mathrm{L}$ of extract with $3 \mathrm{~mL}$ of freshly prepared FRAP solution and incubated it at $37^{\circ} \mathrm{C}$ for $4 \mathrm{~min}$. Absorbance was measured at $595 \mathrm{~nm}$ and converted to the concentration using the standard graphic prepared with $\mathrm{FeSO}_{4}$ (in the range of $0.1-$ $10 \mathrm{mmol} / \mathrm{L}$ ). The analysis was done in triplicate and data presented as $\mu \mathrm{mol} / \mathrm{L}$ of $\mathrm{FeSO}_{4}$ equivalent per gram of propolis (30).

\section{Determination of anticytotoxic potential of propolis extracts}

For cytotoxicity tests we used human peripheral lymphocytes from blood samples donated by healthy volunteers (two men and two women), whose participation was approved by the Ethics Committee of the Kafkas University Faculty of Medicine (approval no. 80576354050-99/158). $10 \mathrm{~mL}$ of whole blood was collected with a sterile syringe from each donor. Mitomycin C (MMC) was used a cytotoxic agent (positive control) in the concentration of $0.25 \mu \mathrm{g} / \mathrm{mL}(0.74 \mu \mathrm{mol} / \mathrm{L})$, which was based on our 
preliminary tests and an investigation by Kocaman and Topaktaş (31), who used mitotic index as toxicological endpoint. Lymphocyte viability was tested with 3-(4,5-dimethylthiazol-2-yl)-2,5-diphenyltetrazolium bromide (MTT), which determines cellular metabolic activity (32). The lymphocytes were first cultured in a PBMAX $^{\mathrm{TM}}$ karyotyping medium (ThermoFisher Scientific Inc., Waltham, MA, USA) and then isolated from whole blood with a Histopaque ${ }^{\circledR}-1077$ solution (Sigma-Aldrich). Isolated cells were counted, placed into the PB-MAX ${ }^{\mathrm{TM}}$ karyotyping medium ( 75 cells $/ \mu \mathrm{L}$ of the medium), and incubated in a $5 \% \mathrm{CO}_{2}$ Forma incubator (ThermoFisher Scientific Inc.) at $37{ }^{\circ} \mathrm{C}$ for $72 \mathrm{~h}$. Propolis extracts were added at different concentrations either $24 \mathrm{~h}$ or $48 \mathrm{~h}$ after incubation started to see their 48 or $24 \mathrm{~h}$ effect on the lymphocytes. The concentrations used were based on preliminary $24 \mathrm{~h} \mathrm{LC}_{50}$ test as follows: $500 \mu \mathrm{g} / \mathrm{mL}\left(\mathrm{LC}_{50}\right), 250 \mu \mathrm{g} / \mathrm{mL}\left(1 / 2 \mathrm{LC}_{50}\right)$, $125 \mu \mathrm{g} / \mathrm{mL}\left(1 / 4 \mathrm{LC}_{50}\right)$, and $62.5 \mu \mathrm{g} / \mathrm{mL}\left(1 / 8 \mathrm{LC}_{50}\right)$. They were added to cultures with or without $0.25 \mu \mathrm{g} / \mathrm{mL}$ $(0.74 \mu \mathrm{mol} / \mathrm{L})$ of MMC. Solvent control consisted of cultures with added ethanol as solvent $(10 \mu \mathrm{L} / \mathrm{mL})$ and negative control of untreated cultures in the medium. Four tubes were prepared for each propolis concentration and controls. After $24 \mathrm{~h}$ or $48 \mathrm{~h}$ of exposure to propolis, three measurements were done to evaluate cell viability using the MTT cell proliferation assay kit $\left(\right.$ Vybrant $^{\mathbb{R}}$, ThermoFisher Scientific Inc.) according to the kit protocol. The cells were seeded into wells of a microplate and $10 \mu \mathrm{L}$ of $12 \mathrm{mmol} / \mathrm{L}$ MTT was added to each well. The microplate was incubated at $37^{\circ} \mathrm{C}$ at $5 \% \mathrm{CO}_{2}$ for $4 \mathrm{~h}$. Absorbance was measured at $540 \mathrm{~nm}$ on a microplate reader $\left(\mathrm{EON}^{\mathrm{TM}}\right.$, BioTek, Winooski, VT, USA), and cell viability calculated using the formula provided by Cheki et al. (33).

\section{Determination of propolis antioxidant activity against model oxidant}

MCF-7 human breast cancer cells [American Type Culture Collection (ATCC), Manassas, VA, USA] were cultured aseptically in Dulbecco's modified Eagle's medium (DMEM; Invitrogen, Thermo Fisher Scientific Inc.) containing $10 \%$ foetal bovine serum (FBS; PAA Laboratories, GE Healthcare, Chicago, IL, USA), $1 \%$ antibiotic solution $(100 \mathrm{IU} / \mathrm{mL}$ penicillin and $0.1 \mathrm{mg} / \mathrm{mL}$ streptomycin) (Sigma-Aldrich) at $37^{\circ} \mathrm{C}$ and $5 \% \mathrm{CO}_{2}$. The medium was removed at $80 \%$ cell growth, and trypsinEDTA solution (Gibco, ThermoFisher Scientific Inc.) was added until it covered the plate surface $(8-10 \mathrm{~mL})$. Separated cells were collected and dissolved in completeDMEM after removing the trypsin solution. Oxidative stress was tested in MCF-7 cells treated with $0.25 \mu \mathrm{g} / \mathrm{mL}$ of MMC $(0.74 \mu \mathrm{mol} / \mathrm{L})$ and propolis extracts from both provinces in one of the following concentrations: $32.5,65,125,250$, or $500 \mu \mathrm{g} / \mathrm{mL}$. Antioxidative activity of propolis was established as reduction in respect to positive control treated with MMC alone. For negative control we used MCF-7 cells in culture and for solvent control MCF-7 cells treated with $10 \mu \mathrm{L} / \mathrm{mL}$ of ethanol. Oxidative stress was determined by measuring thiobarbituric acid reactive substances (TBARS) using a method described by Jain (34) and modified by Do et al. (35). $400 \mu \mathrm{L}$ methanol containing $0.01 \%$ butylated hydroxytoluene and $500 \mu \mathrm{L} 1 \%$ thiobarbituric acid dissolved in $1 \%$ sulphuric acid was mixed with $100 \mu \mathrm{L}$ supernatant. The mixture was vortexed and then incubated at $100{ }^{\circ} \mathrm{C}$ for $15 \mathrm{~min}$. The absorbance of the resulting supernatant was obtained at 532 and $600 \mathrm{~nm}$ and converted to $\mathrm{nmol} / \mathrm{mg}$ protein using a standard curve prepared with 1,1',3,3'-tetramethoxypropane. Total protein was measured using a modified Lowry method as described elsewhere (36).

\section{Determination of propolis anticarcinogenic activity}

MCF-7 cells were cultured and treated as described in the above subsection. Cells were counted in a Thoma counting chamber (Isolab Laborgeräte $\mathrm{GmbH}$ ) under a microscope (Olympus Corp., Tokyo, Japan) at 10x magnification and seeded onto a 6 -well plate (4500 cells per well). The plates were incubated at $37{ }^{\circ} \mathrm{C}$ and $5 \% \mathrm{CO}_{2}$ for $24 \mathrm{~h}$, treated and incubated for another $24 \mathrm{~h}$.

Apoptotic cells were counted using the Roche In Situ Cell Death Detection Kit according to the producer's instructions (Roche Diagnostics GmbH, Mannheim, Germany). Treated cells were incubated with $0.002 \%$ Triton $\mathrm{X}-100$ for $10 \mathrm{~min}$, added $50 \mu \mathrm{L}$ of terminal deoxynucleotidyl transferase (dUTP) nick end labelling (TUNEL) master mix per well, and incubated at $37^{\circ} \mathrm{C}$ and $5 \% \mathrm{CO}_{2}$ for another $80 \mathrm{~min}$. Red-stained TUNEL-positive cells were visualised under a fluorescent microscope (BX43 equipped with DP74 camera, Olympus Corp.) at 20x magnification and quantified with Image Processing and Analysis in Java version $1.51 \mathrm{~h}$ software (ImageJ; National Institutes of Health, Bethesda, MD).

\section{Determination of propolis antimicrobial activity}

Propolis extracts were sterilised through $0.22 \mu \mathrm{m}$ Millipore filters and their antimicrobial potential tested by disc diffusion or broth microdilution $(37,38)$ against known bacterial and fungal pathogens, cultured in Mueller-Hinton agar and $2 \%$ Sabouraud dextrose agar, respectively. These included gram-positive bacteria Bacillus megaterium (Kahramanmaraş Sütçü İmam University Department of Biology, Kahramanmaraş, Turkey) and Staphylococcus aureus (ATCC 6538), gram-negative Pseudomonas aeruginosa (ATCC 9027) and Klebsiella pneumoniae, and fungi Yarrowia lipolytica and Candida albicans (Kahramanmaraş Sütçü İmam University). Gentamycin (Gen), ampicillin (Amp), erythromycin (Ery), and penicillin (Pen) were used as positive controls for the disc diffusion method. After $48 \mathrm{~h}$ of treatment, inhibition zones were measured with a digital calliper. All the tests were 
triplicated, and the results presented as means \pm standard deviations.

As the fungal species and P. aeruginosa showed no inhibition zone with broth microdilution method in our study, we tested antimicrobial activity of propolis against these species only with the disc diffusion method (39).

For broth microdilution method we diluted the propolis extracts to $0.67-173.5 \mu \mathrm{g} / \mathrm{mL}$ for the Erzurum and to 0.95-245.7 $\mu \mathrm{g} / \mathrm{mL}$ for the Ardahan samples according to our preliminary experiments. After incubation at $37^{\circ} \mathrm{C}$ for $18 \mathrm{~h}, 0.5 \%$ 2,3,5-triphenyltetrazolium chloride (TTC) was added, and incubation continued at $37{ }^{\circ} \mathrm{C}$ for another $30 \mathrm{~min}$. Plate wells without colour change were considered containing minimal inhibition concentrations (MIC) of propolis (40).

\section{Statistical analyses}

All statistical analyses were run on SPSS Statistics for Windows, Version 17.0 (SPSS Inc., Chicago, IL, USA). Normality of distribution was assessed with the KolmogorovSmirnov test, except for the MTT assay, for which we used the Shapiro-Wilk test. For the data that did not show normal distribution we ran the non-parametric Kruskal-Wallis test,

Table 1 Comparison of mineral composition of A. m. caucasica propolis samples collected from the Ardahan and Erzurum provinces of Turkey

\begin{tabular}{|c|c|c|}
\hline Element & $\begin{array}{c}\text { Ardahan } \\
\text { (mg/kg) }\end{array}$ & $\begin{array}{c}\text { Erzurum } \\
(\mathrm{mg} / \mathrm{kg})\end{array}$ \\
\hline Co & $0.14 \pm 0.04^{\mathrm{a}}$ & $0.25 \pm 0.06^{\mathbf{b}}$ \\
\hline $\mathrm{Se}$ & $0.038 \pm 0.016$ & $0.025 \pm 0.006$ \\
\hline $\mathrm{Li}$ & $0.20 \pm 0.04$ & $0.22 \pm 0.04$ \\
\hline $\mathrm{Cd}$ & $0.005 \pm 0.006$ & $0.004 \pm 0.004$ \\
\hline As & $0.13 \pm 0.02^{\mathrm{a}}$ & $0.22 \pm 0.049^{b}$ \\
\hline $\mathrm{Cr}$ & $0.98 \pm 0.22^{\mathrm{a}}$ & $1.39 \pm 0.18^{b}$ \\
\hline $\mathrm{Ni}$ & $1.08 \pm 0.23$ & $1.53 \pm 0.34$ \\
\hline $\mathrm{Pb}$ & $0.83 \pm 0.19$ & $0.97 \pm 0.19$ \\
\hline $\mathrm{Cu}$ & $2.45 \pm 0.16$ & $2.01 \pm 0.79$ \\
\hline $\mathrm{Ca}$ & $269.42 \pm 51.83^{\mathrm{a}}$ & $428.97 \pm 76.28^{b}$ \\
\hline $\mathrm{Mg}$ & $376.17 \pm 85.91$ & $560.21 \pm 171.45$ \\
\hline $\mathrm{K}$ & $1156.06 \pm 278.58$ & $2607.36 \pm 1468.87$ \\
\hline $\mathrm{Mn}$ & $5.297 \pm 0.71$ & $7.47 \pm 3.27$ \\
\hline $\mathrm{Na}$ & $193.19 \pm 15.34$ & $203.47 \pm 9.58$ \\
\hline $\mathrm{Zn}$ & $30.05 \pm 7.30$ & $41.77 \pm 19.65$ \\
\hline $\mathrm{Fe}$ & $428.51 \pm 77.75$ & $507.62 \pm 287.13$ \\
\hline \multirow[t]{2}{*}{$\mathrm{Al}$} & $408.46 \pm 88.17$ & $406.86 \pm 202.20$ \\
\hline & $\%$ of total mass & $\%$ of total mass \\
\hline $\mathrm{N}$ & $0.42 \pm 0.09$ & $0.35 \pm 0.02$ \\
\hline $\mathrm{C}$ & $66.84 \pm 1.38$ & $64.06 \pm 6.38$ \\
\hline $\mathrm{S}$ & ND & ND \\
\hline
\end{tabular}

Data are given as mean \pm standard deviation $(N=3)$. Different superscript letters in the same row denote significant difference $(P<0.05)$. ND - not detected followed by the post-hoc Mann-Whitney $U$-test. Data with normal distribution were analysed with one-way analysis of variance (ANOVA). Homogeneity of variance was tested with Levene's test. Duncan post-hoc test was applied for homogeneous subsets, while Dunnett's $C$ test was used for non-homogeneous ones. All data are presented as means \pm standard deviations. Significance ( $P$-value) was set at 0.05 .

\section{RESULTS AND DISCUSSION}

Table 1 presents the mineral composition of propolis from both provinces. It was statistically similar except for $\mathrm{Co}$, As, $\mathrm{Cr}$, and $\mathrm{Ca}$, which was higher in the Erzurum samples. The order of abundance in the Ardahan propolis samples was $\mathrm{K}>\mathrm{Fe}=\mathrm{Al}=\mathrm{Mg}=\mathrm{Ca}>\mathrm{Na}>\mathrm{Zn}>\mathrm{Mn}>\mathrm{Cu}>\mathrm{Ni}=$ $\mathrm{Cr}=\mathrm{Pb}>\mathrm{Li}=\mathrm{Co}=\mathrm{As}>\mathrm{Se}>\mathrm{Cd}$ and in the Erzurum samples $\mathrm{K}>\mathrm{Mg}=\mathrm{Fe}=\mathrm{C} \mathrm{a}=\mathrm{Al}>\mathrm{Na}>\mathrm{Zn}>\mathrm{Mn}>\mathrm{Cu}=\mathrm{C} \mathrm{r}$ $\geq \mathrm{Ni}=\mathrm{Pb}>\mathrm{Li}=\mathrm{Co}=\mathrm{As}>\mathrm{Se}>\mathrm{Cd}$. For comparison, reports on propolis mineral composition from Croatia (21) and Spain (41) single out $\mathrm{Ca}, \mathrm{Mg}, \mathrm{K}, \mathrm{Al}, \mathrm{Fe}, \mathrm{Na}$, and $\mathrm{Zn}$ as the most abundant. Spanish propolis was reported similar or higher $\mathrm{Cd}, \mathrm{Ni}, \mathrm{Fe}$, and $\mathrm{Zn}$ levels as did Polish (42).

According to Kruskal-Wallis $H$ test, Ardahan propolis $\mathrm{Fe}, \mathrm{Al}, \mathrm{Mg}$, and $\mathrm{Ca}$ levels $(P=0.135)$ can be grouped in one cluster, $\mathrm{Ni}, \mathrm{Pb}$, and $\mathrm{Cr}(P=0.393)$ in another, and $\mathrm{Li}, \mathrm{Co}$, and As $(P=0.148)$ in yet another cluster. Similar is true for the Erzurum samples with a minor exception for $\mathrm{Cu}$ in the second cluster. $\mathrm{Fe}, \mathrm{Al}, \mathrm{Mg}$, and $\mathrm{Ca}$ formed one cluster ( $P=0.599), \mathrm{Cu}, \mathrm{Ni}, \mathrm{Pb}$, and $\mathrm{Cr}(P=0.090)$ the second, and $\mathrm{Li}, \mathrm{Co}$, and As $(P=0.587)$ the third.

We believe that similarities in the mineral composition between the propolis from the two provinces is owed to their geographic vicinity. Similar reason may explain the highest $\mathrm{Ca}$ content in Turkey in propolis from these two adjacent provinces reported by Yozgat and Sivas (43).

Propolis from both our provinces had considerably lower Cd levels than reported in other Turkish provinces (44), most likely because these two provinces have little industry. However, $\mathrm{Pb}$ and $\mathrm{Cr}$ levels were much higher than in the rest of Turkey (44) and some regions of Croatia (21). Similar or lower levels than ours were reported in Polish and Spanish propolis $(41,42)$. While no data are available about soil mineral composition for both provinces, Erzurum is known for $\mathrm{Cu}, \mathrm{Pb}, \mathrm{Zn}$, and $\mathrm{Cr}$ mining areas (44), especially near the Ardahan province border. This may partly explain the highest levels of $\mathrm{Pb}$ and $\mathrm{Cr}$.

As and $\mathrm{Al}$ levels deserve special attention, those in the Erzurum propolis in particular. They are in the range reported in previous studies $(21,41)$ and are below the acceptable daily intake thresholds (300-1400 $\mu \mathrm{g}$ /day for $\mathrm{Al}, 20-514 \mu \mathrm{g} /$ day for $\mathrm{Pb}, 20-250 \mu \mathrm{g} /$ day for $\mathrm{Cr}, 10-60 \mu \mathrm{g} /$ day for Cd, and 12-25 $\mu \mathrm{g} /$ day for As) (45).

We were surprised to see that propolis from neither province contained any sulphur, especially as it is an 
Table 2 Comparison of fatty acid content in A. m. caucasica propolis samples collected from the Ardahan and Erzurum provinces of Turkey

\begin{tabular}{|c|c|c|c|}
\hline Fatty Acid & $\begin{array}{l}\text { Retention time } \\
\text { (min) }\end{array}$ & $\begin{array}{c}\text { Ardahan } \\
(\%)\end{array}$ & $\begin{array}{c}\text { Erzurum } \\
(\%)\end{array}$ \\
\hline \multicolumn{4}{|l|}{ Saturated } \\
\hline Caproic acid & 6.54 & - & 8.85 \\
\hline Caprylic acid & 9.24 & 0.26 & - \\
\hline Decanoic acid (capric acid) & 13.85 & $1.14-1.47$ & 0.08 \\
\hline Undecanoic acid & 17.80 & 0.67 & - \\
\hline Dodecanoic acid (lauric acid) & 21.53 & $24.39-36.95$ & $49.62-54.27$ \\
\hline Tridecanoic acid & 25.38 & $5.00-6.59$ & $6.29-8.10$ \\
\hline Tetradecanoic acid (myristic acid) & 30.81 & $4.68-5.86$ & 8.66 \\
\hline Pentadecanoic acid & 34.13 & $6.97-8.85$ & - \\
\hline Hexadecanoic acid (palmitic acid) & 36.89 & $0.84-0.89$ & 1.53 \\
\hline Heptadecanoic acid (margaric acid) & 41.10 & $1.03-1.64$ & $0.54-1.12$ \\
\hline Octadecanoic acid (stearic acid) & 44.19 & 1.86 & $1.48-2.12$ \\
\hline Eicosanoic acid (arachidic acid) & 49.47 & - & $3.13-4.43$ \\
\hline Heneicosanoic acid & 54.98 & 1.21 & $1.57-2.05$ \\
\hline Docosanoic acid (behenic acid) & 56.66 & 0.54 & $0.78-1.35$ \\
\hline Tricosanoic acid & 59.78 & $0.31-2.44$ & 0.26 \\
\hline Lignoceric acid & 62.16 & $0.45-0.57$ & $0.22-0.45$ \\
\hline TOTAL & & $49.4-69.8$ & 83.0-93.3 \\
\hline \multicolumn{4}{|l|}{ Monounsaturated } \\
\hline 9-tetradecenoic acid (myristoleic acid) & 32.80 & - & 0.49 \\
\hline cis-10-pentadecenoic acid & 36.57 & $3.36-4.70$ & $0.88-1.69$ \\
\hline cis-9-hexadecenoic acid (palmitoleic acid) & 39.52 & $1.48-2.61$ & $0.32-2.83$ \\
\hline cis-10-heptadecenoic acid & 42.58 & $3.18-3.35$ & - \\
\hline trans-9-octadecenoic acid (elaidic acid) & 45.97 & - & $0.59-1.73$ \\
\hline cis-9-octadecenoic acid (oleic acid) & 46.98 & $1.75-1.92$ & $0.56-1.15$ \\
\hline cis-11-eicosenoic acid (gondoic acid) & 51.98 & 1.14 & $1.61-2.28$ \\
\hline cis-13-docosenoic acid (erucic acid) & 57.64 & 0.66 & - \\
\hline cis-15-tetracosenoic acid (nervonic acid) & 65.02 & $0.54-0.79$ & $0.16-0.26$ \\
\hline TOTAL & & $12.1-15.2$ & $4.6-10.4$ \\
\hline \multicolumn{4}{|l|}{ Polyunsaturated } \\
\hline 9,12-octadecadienoic acid (linolelaidic acid) & 47.80 & - & $1.04-1.09$ \\
\hline Linoleic acid & 48.20 & $1.42-1.89$ & $7.89-11.46$ \\
\hline Gamma-linolenic acid & 50.96 & $0.61-1.26$ & $1.10-1.39$ \\
\hline Linolenic acid & 53.33 & $0.65-0.79$ & $0.14-0.28$ \\
\hline cis-11,14-eicosadienoic acid & 55.09 & 1.44 & 0.26 \\
\hline cis-8,11,14-eicosatrienoic acid & 57.22 & $16.30-22.14$ & 0.16 \\
\hline cis-11,14,17-eicosatrienoic acid & 58.10 & $2.00-2.14$ & 1.04 \\
\hline all-cis-5,8,11,14-eicosatetraenoic acid (arachidonic acid) & 59.28 & $0.94-2.69$ & $0.66-0.92$ \\
\hline cis-13, 16-docosadienoic acid & 60.93 & $0.65-0.72$ & - \\
\hline cis-5,8,11,14,17-eicosapentaenoic acid (timnodonic acid) & 64.00 & $0.79-2.16$ & $0.07-0.40$ \\
\hline cis-4,7,10,13,16,19-docosahexaenoic acid (cervonic acid) & 66.92 & $0.60-0.75$ & $0.22-0.45$ \\
\hline TOTAL & & 25.4-36.0 & 12.6-17.5 \\
\hline
\end{tabular}


important component of various biological compounds. Similar absence of sulphur was reported in other Turkish provinces (43).

Table 2 shows that propolis fatty acid content differed between the provinces. Such variation has also been found in the rest of Turkey (46) and other countries of the world, such as Algeria (47), Brazil (48), and New Zealand (49).

Of the 36 fatty acids determined in the samples, six were found only in the Ardahan propolis and five only in the Erzurum propolis. The Ardahan propolis had higher mono- and polyunsaturated fatty acid content than the Erzurum propolis (12.1-15.2\% vs 4.6-10.4\% and 25.4$36.0 \%$ vs $12.6-17.5 \%$, respectively). The Erzurum propolis, in turn, had much higher saturated fatty acid content (83.0-93.3\% vs 49.4-69.8\%).

While our findings show the highest content of lauric acid in the $A$. $m$. caucasica propolis from both provinces, Silici and Kutluca (17) reported only oleic and palmitic acid in Erzurum propolis collected from three bee races. Palmitic acid levels were the highest in $A$. m. carnica, followed by A. m. anatoliaca, and then A. m. caucasica propolis. It was also the most common in reports from Brasil (48), New Zealand (49), and Jordan (50).

The saturated fatty acid content of the Ardahan propolis was between the one reported for Algerian (41\%) (47) and Romanian (71 \%) (51) propolis samples, while the Erzurum propolis had much higher saturated fatty acid content. Judging by earlier reports from Erzurum (17) and Brazil $(48,52)$, not only did forage on several botanical species but also genetic differences influence hydrocarbon chemistry of propolis samples.

Table 3 shows vitamin $\mathrm{C}$ and carbohydrate content in propolis from both provinces. Vitamin C content was higher in the Ardahan propolis and was comparable to the one reported in India (53). Ardahan propolis also had higher fructose and glucose but lower sucrose content than the Erzurum propolis. According to reports from Egypt (54), Canary Islands (55), and South East England (56), propolis fructose, glucose, and sucrose content very much depended on plant origin and geographic region.

Tables 4 and 5 show differences in alkaloid, organic acid, flavonoid, and phenolic content in propolis between

Table 3 Comparison of vitamin $\mathrm{C}$ and carbohydrate content in $A$. $m$. caucasica propolis samples collected from the Ardahan and Erzurum provinces of Turkey

\begin{tabular}{lcc}
\hline & $\begin{array}{c}\text { Ardahan } \\
(\mu \mathrm{g} / \mathrm{g} \text { dry weight })\end{array}$ & $\begin{array}{c}\text { Erzurum } \\
(\boldsymbol{\mu} \mathrm{g} / \mathrm{g} \text { dry weight })\end{array}$ \\
\hline Vitamin C & $40.31 \pm 2.97^{\mathrm{a}}$ & $16.18 \pm 1.48^{\mathrm{b}}$ \\
\hline Fructose & $1.58 \pm 0.30^{\mathrm{a}}$ & $0.86 \pm 0.18^{\mathrm{b}}$ \\
\hline Glucose & $0.98 \pm 0.20^{\mathrm{a}}$ & $0.39 \pm 0.05^{\mathrm{b}}$ \\
\hline Sucrose & $0.15 \pm 0.04^{\mathrm{a}}$ & $0.69 \pm 0.19^{\mathrm{b}}$ \\
\hline
\end{tabular}

Data are given as mean \pm standard deviation $(N=3$ for vitamin $\mathrm{C}$, $N=4$ for carbohydrates). Letters a and b denote significant difference between parameters presented in the same row $(P<0.001$ for vitamin $\mathrm{C}, P<0.01$ for carbohydrates) the two provinces. The Ardahan samples had 17 and Erzurum 16 alkaloid, organic acid, and flavonoid compounds. Gallic acid, vanillic acid, benzoic acid, sorbic acid, naringenin, and myricetin were not found in samples from either province with HPLC analysis, but GC-MS revealed benzoic acid and naringenin peaks in the Ardahan propolis and naringenin peak in the Erzurum propolis. Ferulic acid in the Erzurum propolis was detected with both HPLC and GC-MS analysis, but only with HPLC in the Ardahan samples. This inconsistency points to the limitations of silylation, or characteristics of a particular column, as already observed in the study of García-Viguera et al. (57).

The Erzurum propolis had higher pinostrobin chalcone, pinocembrin, tectochrysin, naringenin, chrysin, galangin, caffeic acid, and quercetin flavonoid and phenolic content than the Ardahan propolis. All these compounds are known anticarcinogens with or without antioxidant properties. Some have already been reported in the propolis of the three bee races from Erzurum studied earlier $(17,58)$, but our study is the first to report pyrocatechol, isoferulic acid, p-coumaric acid methyl ester, 4',5-dihydroxy-7methoxyflavone, 5-methylisophthalic acid, and 1,2-dimethylcyclopropene. These, however, were not found in the Ardahan propolis.

Of the compounds with known antioxidant and anticarcinogenic potential Ardahan propolis had higher levels of sakuranetin, $p$-coumaric acid, and ferulic acid, while 2,3-dihydrobenzofuran levels were similar to the Erzurum propolis. Unlike the Erzurum propolis, however, it also had benzyl alcohol, guaiacol, benzoic acid, $p$-vinylguaiacol, vanillin, $\beta$-caryophyllene, benzylbenzoate, benzylcinnamate, corydaldine, 6-methoxypiperonal, benzyl 4-acetylbenzoate, 2, 5-bis dimethylamino-3, 9-dimethyl$3 \mathrm{H}-1,3,4,6-$ tetrasacyclopentazulene, and 3,4',7-trimethoxyflavone. Most of the compounds found in the Ardahan and Erzurum were already reported in the rest of Turkey and other countries of Europe. Judging by reports of poplar bud exudates from a number of locations $(46,56$, 59-62), propolis from both our provinces may be categorised as poplar propolis.

Table 6 shows total flavonoid and phenolic content and total antioxidant capacity of propolis samples from both provinces. The Ardahan propolis had 2.18 times higher total phenolic and 1.79 times higher total flavonoid content. As a result, it had significantly higher antioxidant activity, as determined by the FRAP test. We think that the FRAP test is more convenient for this purpose, because the DPPH test showed no significant difference. Our flavonoid and phenolic content findings in the Ardahan propolis were similar to or higher than reported elsewhere for Ardahan and higher than reported for the Turkish province of Ankara (63). In addition, both Ardahan and Erzurum propolis had higher flavonoid and phenolic content than propolis collected from Greece (64), Ireland, Germany (59), and Argentina (65) but lower than Ethiopian propolis (66). Most 


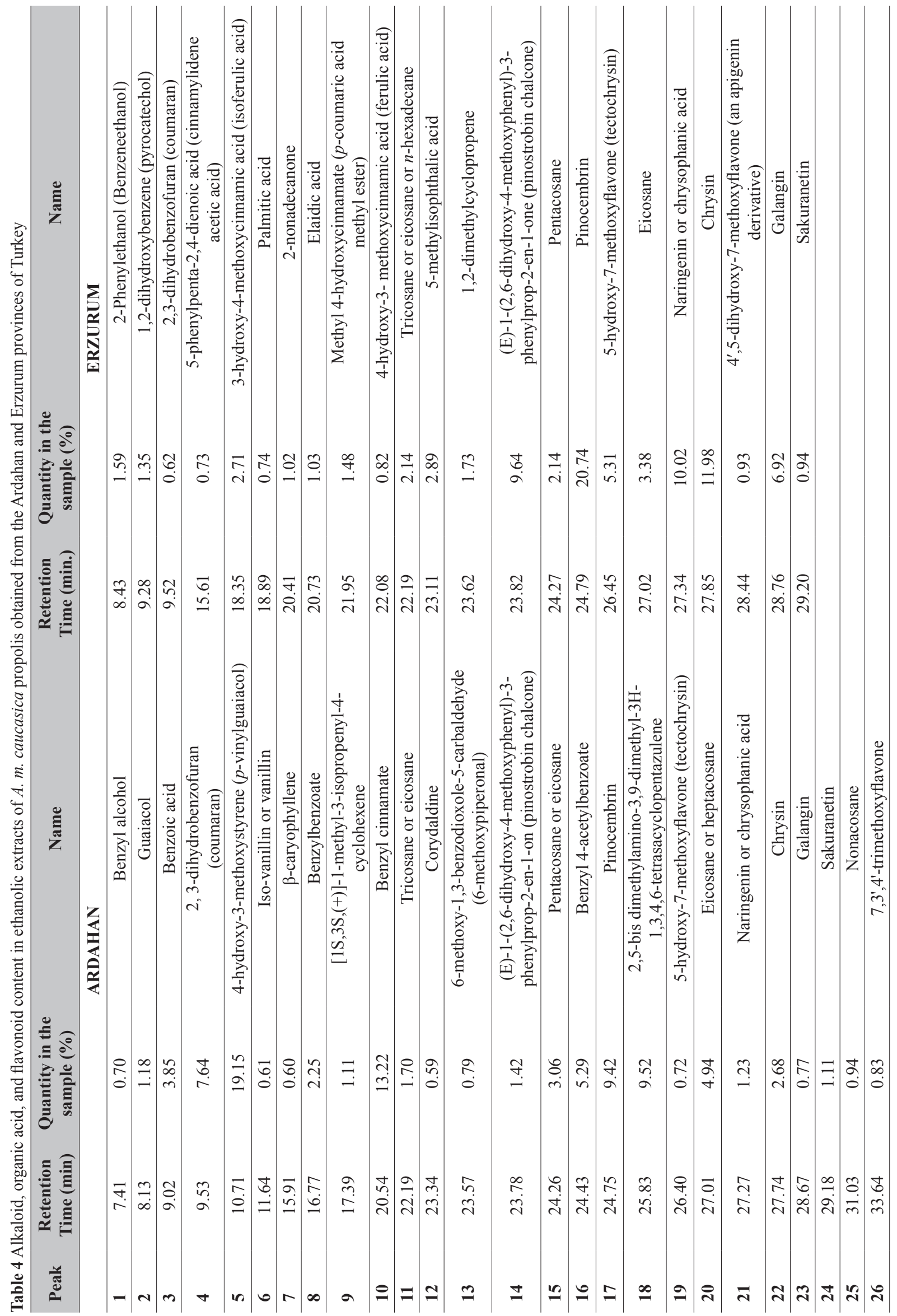


Table 5 Comparison of phenolic acid content in A. m. caucasica propolis samples collected from the Ardahan and Erzurum provinces of Turkey

\begin{tabular}{lcc}
\hline Phenolic acids & $\begin{array}{c}\text { Ardahan } \\
(\mathbf{m g} / \mathbf{k g})\end{array}$ & $\begin{array}{c}\text { Erzurum } \\
\mathbf{( m g / k g})\end{array}$ \\
\hline 3,4,5-trihydroxybenzoic acid (gallic acid) & $\mathrm{ND}$ & $\mathrm{ND}$ \\
\hline 4-hydroxy-3-methoxybenzoic acid (vanillic acid) & $\mathrm{ND}$ & $\mathrm{ND}$ \\
\hline 3,4-dihydroxycinnamic acid (caffeic acid) & 0.033 & 0.046 \\
\hline 4-hydroxycinnamic acid (p-coumaric acid) & 0.042 & 0.008 \\
\hline 4-hydroxy-3,5-dimethoxycinnamic acid (sinapic acid) & $\mathrm{ND}$ & $\mathrm{ND}$ \\
\hline 4-hydroxy-3-methoxycinnamic acid (trans-ferulic acid) & 0.079 & 0.005 \\
\hline Quercetin & 0.018 & 0.054 \\
\hline Benzoic acid & $\mathrm{ND}$ & $\mathrm{ND}$ \\
\hline 2,4-hexadienoic acid (sorbic acid) & $\mathrm{ND}$ & $\mathrm{ND}$ \\
\hline Naringenin & $\mathrm{ND}$ & $\mathrm{ND}$ \\
\hline Myricetin & $\mathrm{ND}$ & $\mathrm{ND}$ \\
\hline
\end{tabular}

ND - not detected

Table 6 Total flavonoid and phenolic content and antioxidant capacity of A. m. caucasica propolis samples obtained from the Ardahan and Erzurum provinces of Turkey

\begin{tabular}{|c|c|c|}
\hline & Ardahan & Erzurum \\
\hline Total flavonoid content ( $\mu$ g quercetin equivalent of total flavonoids $/ \mathrm{g}$ ) & $591.5 \pm 26.2^{\mathrm{a}}$ & $271.7 \pm 2.9^{\mathbf{b}}$ \\
\hline Total phenolic content (mg gallic acid equivalent/g) & $235.5 \pm 5.3^{\mathrm{a}}$ & $131.3 \pm 3.1^{\mathrm{b}}$ \\
\hline DPPH ( $\%$ of control) & $94.9 \pm 0.3^{\mathrm{a}}$ & $94.6 \pm 0.7^{\mathrm{a}}$ \\
\hline FRAP $\left(\mu \mathrm{M} \mathrm{FeSO}_{4}\right.$ equivalent/g) & $4017.7 \pm 16.4^{\mathrm{a}}$ & $3813.2 \pm 3.6^{\mathbf{b}}$ \\
\hline
\end{tabular}

Data are presented as mean \pm standard deviation $(N=3)$. Different superscript letters in the same row denote significant difference $(P<0.05)$. DPPH - 2,2-diphenyl-1-picrylhydrazyl; FRAP - ferric reducing antioxidant power

Table 7 Effects of different concentrations of propolis extracts obtained from Ardahan and Erzurum on the viability of human lymphocytes

\begin{tabular}{|c|c|c|c|c|}
\hline & \multicolumn{4}{|c|}{ Cell viability (\% of control) } \\
\hline & \multicolumn{2}{|c|}{ Ardahan } & \multicolumn{2}{|c|}{ Erzurum } \\
\hline & $24 \mathrm{~h}$ & $48 \mathrm{~h}$ & $24 \mathrm{~h}$ & $48 \mathrm{~h}$ \\
\hline Control & $100.0 \pm 0.0^{\mathrm{a}}$ & $100.0 \pm 0.0$ & $100.0 \pm 0.0$ & $100.0 \pm 0.0^{\mathrm{ab}}$ \\
\hline Solvent control & $97.3 \pm 1.3^{\text {bd }}$ & $102.2 \pm 8.5$ & $96.5 \pm 13.3$ & $89.8 \pm 14.9^{\mathrm{a}}$ \\
\hline $\mathrm{MMC}(0.74 \mu \mathrm{mol} / \mathrm{L})$ & $97.3 \pm 2.6^{\text {be }}$ & $97.7 \pm 1.2$ & $92.4 \pm 13.4$ & $89.1 \pm 14.0^{\mathrm{a}}$ \\
\hline \multicolumn{5}{|l|}{ Propolis extract } \\
\hline $62.5 \mu \mathrm{g} / \mathrm{mL}$ & $98.0 \pm 2.8^{\text {ade }}$ & $102.8 \pm 11.4$ & $99.7 \pm 13.5$ & $93.9 \pm 13.9^{\mathrm{a}}$ \\
\hline $125 \mu \mathrm{g} / \mathrm{mL}$ & $102.9 \pm 5.7^{\text {acde }}$ & $105.2 \pm 7.9$ & $104.0 \pm 19.6$ & $100.7 \pm 19.5^{\mathrm{ab}}$ \\
\hline $250 \mu \mathrm{g} / \mathrm{mL}$ & $107.0 \pm 1.8^{\mathrm{c}}$ & $102.9 \pm 2.1$ & $118.1 \pm 17.8$ & $113.3 \pm 20.3^{\mathrm{abc}}$ \\
\hline $500 \mu \mathrm{g} / \mathrm{mL}$ & $116.5 \pm 6.6^{\mathrm{f}}$ & $108.8 \pm 3.9$ & $139.9 \pm 22.5$ & $127.0 \pm 20.0^{\mathrm{c}}$ \\
\hline \multicolumn{5}{|l|}{ Propolis + MMC } \\
\hline $62.5 \mu \mathrm{g} / \mathrm{mL}+\mathrm{MMC}$ & $99.5 \pm 3.2^{\mathrm{ab}}$ & $101.1 \pm 7.7$ & $98.9 \pm 19.2$ & $94.7 \pm 16.7^{\mathrm{ab}}$ \\
\hline $125 \mu \mathrm{g} / \mathrm{mL}+\mathrm{MMC}$ & $99.6 \pm 1.9^{\mathrm{ab}}$ & $99.3 \pm 7.6$ & $116.4 \pm 41.1$ & $109.1 \pm 10.3^{\mathrm{abc}}$ \\
\hline $250 \mu \mathrm{g} / \mathrm{mL}+\mathrm{MMC}$ & $100.5 \pm 6.1^{\mathrm{abc}}$ & $101.6 \pm 6.0$ & $117.2 \pm 16.2$ & $119.6 \pm 11.7^{\mathbf{b c}}$ \\
\hline $500 \mu \mathrm{g} / \mathrm{mL}+\mathrm{MMC}$ & $112.5 \pm 2.8^{\mathrm{f}}$ & $113.0 \pm 5.5$ & $138.9 \pm 23.8$ & $133.5 \pm 19.6^{\mathrm{c}}$ \\
\hline
\end{tabular}

Data are presented as mean \pm standard deviation $(N=12)$. Different superscript letters in the same column denote significant difference $(P<0.05)$. MMC - mitomycin C 

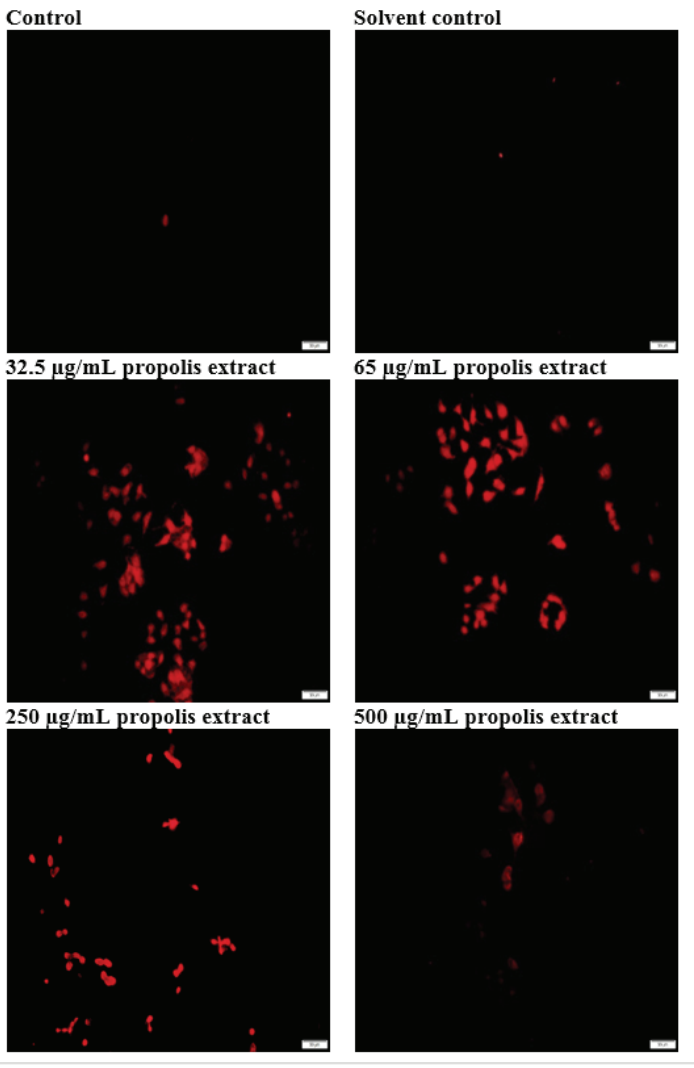

$65 \mu \mathrm{g} / \mathrm{mL}$ propolis extract

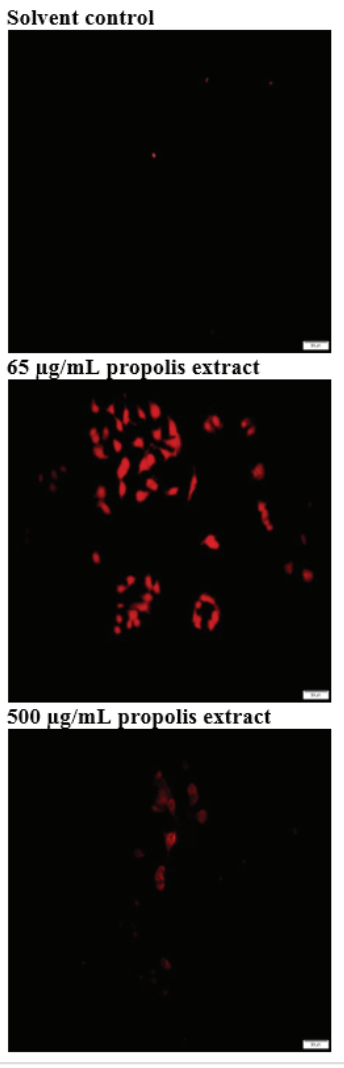

$500 \mu \mathrm{g} / \mathrm{mL}$ propolis extract

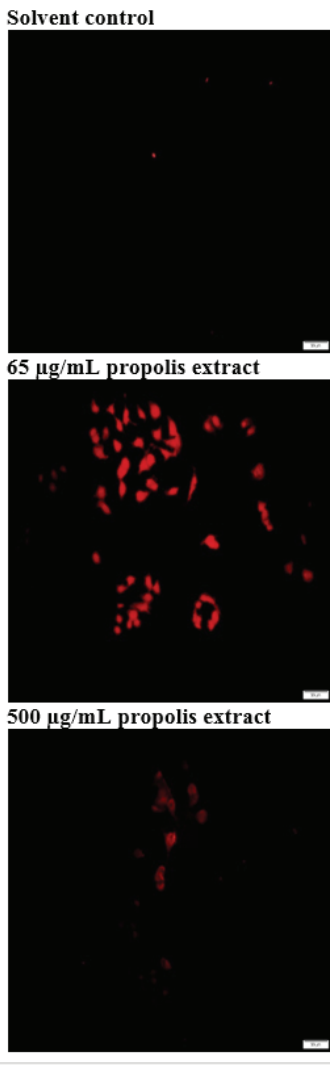

Ardahan

c
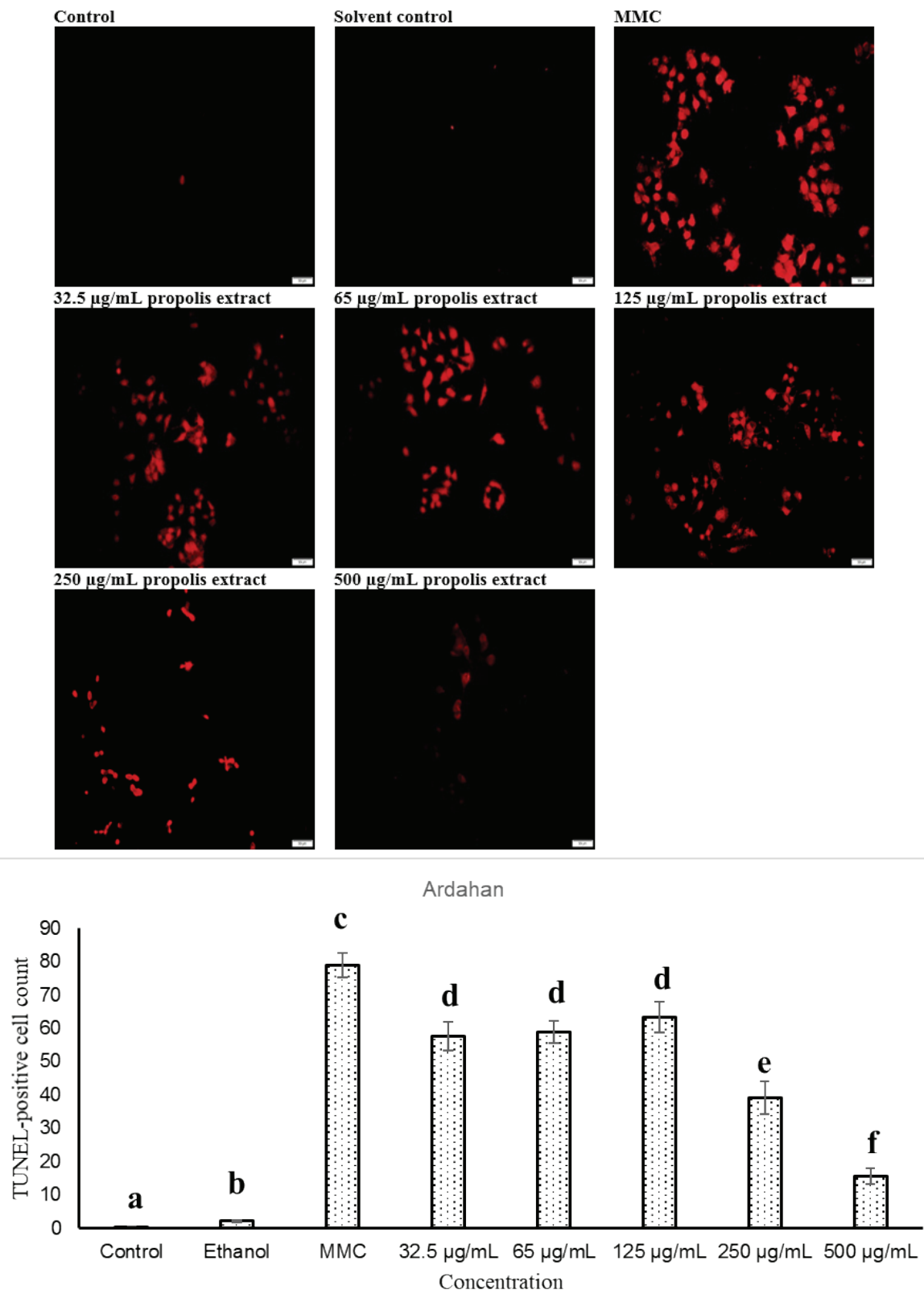

$125 \mu \mathrm{g} / \mathrm{mL}$ propolis extract

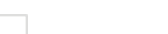
Table 8 Protective effects of the Ardahan and Erzurum propolis against oxidation in MCF-7 cells exposed to mitomycin C

\begin{tabular}{|c|c|c|}
\hline & \multicolumn{2}{|c|}{ TBARS (nmol/mL) } \\
\hline Control & \multicolumn{2}{|c|}{$0.40 \pm 0.02^{\mathrm{a}}$} \\
\hline Solvent control & \multicolumn{2}{|c|}{$0.41 \pm 0.02^{\mathrm{a}}$} \\
\hline $\mathrm{MMC}(0.74 \mu \mathrm{mol} / \mathrm{L})$ & \multicolumn{2}{|c|}{$0.40 \pm 0.05^{\mathrm{a}}$} \\
\hline Propolis + MMC & Ardahan & Erzurum \\
\hline $32.5 \mu \mathrm{g} / \mathrm{mL}$ & $0.03 \pm 0.02^{\mathrm{b}}$ & $0.03 \pm 0.02^{\mathrm{b}}$ \\
\hline $65 \mu \mathrm{g} / \mathrm{mL}$ & $0.10 \pm 0.02^{\mathrm{bcd}}$ & $0.05 \pm 0.01^{\mathrm{b}}$ \\
\hline $125 \mu \mathrm{g} / \mathrm{mL}$ & $0.06 \pm 0.02^{\mathrm{bc}}$ & $0.07 \pm 0.02^{\mathrm{bcd}}$ \\
\hline $250 \mu \mathrm{g} / \mathrm{mL}$ & $0.09 \pm 0.01^{\mathrm{bcd}}$ & $0.10 \pm 0.03^{\mathrm{bcc}}$ \\
\hline $500 \mu \mathrm{g} / \mathrm{mL}$ & $0.15 \pm 0.04^{\mathrm{cd}}$ & $0.16 \pm 0.04^{\mathrm{d}}$ \\
\hline
\end{tabular}

Data are presented as mean \pm standard error $(N=12$ for control, solvent control, and MMC groups; $N=4-6$ for propolis + MMC groups). Different superscript letters denote significant difference $(P<0.05)$. MMC - mitomycin C

Even though MMC cytotoxicity was low, the Erzurum and Ardahan propolis extracts showed their protective effects against MMC and solvent (Table 7) by restoring cell viability to normal (control) there were it was reduced. Their protective (proliferative) effect was concentrationdependent and independent of the presence of MMC. Similar effects of propolis components were reported in a Brazilian green propolis water extract (72).

Table 8 shows the protective effects of propolis from both provinces against lipid peroxidation caused by MMC. Like with human peripheral lymphocytes, MMC did not cause lipid peroxidation in the MCF-7 breast cancer cell line, which confirms earlier reports that MMC may have a low oxidative potential against cancer cells (73) and erythrocytes in Sprague-Dawley rats (74).

Propolis extracts from both provinces were the most effective at lowering lipid peroxide levels in MCF-7 cells at their lowest concentrations, and this effect generally weakened as propolis concentrations increased, especially with the Erzurum propolis (Table 8). Similar was observed in a Croatian study (75) in which propolis at $100 \mathrm{mg} / \mathrm{kg}$ showed better effect at lowering lipid peroxide levels in female CBA/Hr mice plasma than at $300 \mathrm{mg} / \mathrm{kg}$. Antioxidants in propolis such as phenols and especially flavonoids can become oxidants as their concentrations increase (76). For example, galangin, chrysin, and pinocembrin may start to behave as electron-carriers in the presence of metals such as iron and increase oxidative stress on the cell, as reported in human gastric and lung adenocarcinoma cell lines exposed to a New Zealand propolis extract (77).

Figures 1 and 2 show the anticarcinogenic potential of A. m. caucasica propolis extracts from both provinces on MCF-7 human breast cancer cell line. The most effective concentrations were 65 and $125 \mu \mathrm{g} / \mathrm{mL}$, and the Erzurum propolis was significantly more potent at these concentrations than even MMC, let alone the Ardahan propolis. A similar pattern was reported for propolis from East Java, Indonesia (78), and Turkish propolis samples collected from the Sakarya, Kemaliye, Çanakkale, Van, Yalova, and Ankara

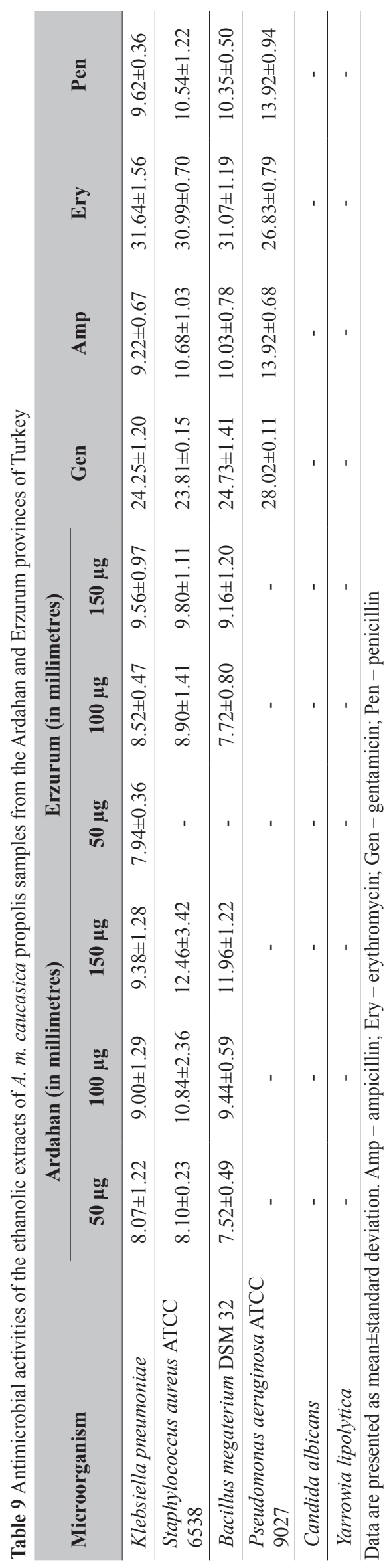





$250 \mu \mathrm{g} / \mathrm{mL}$ propolis extract
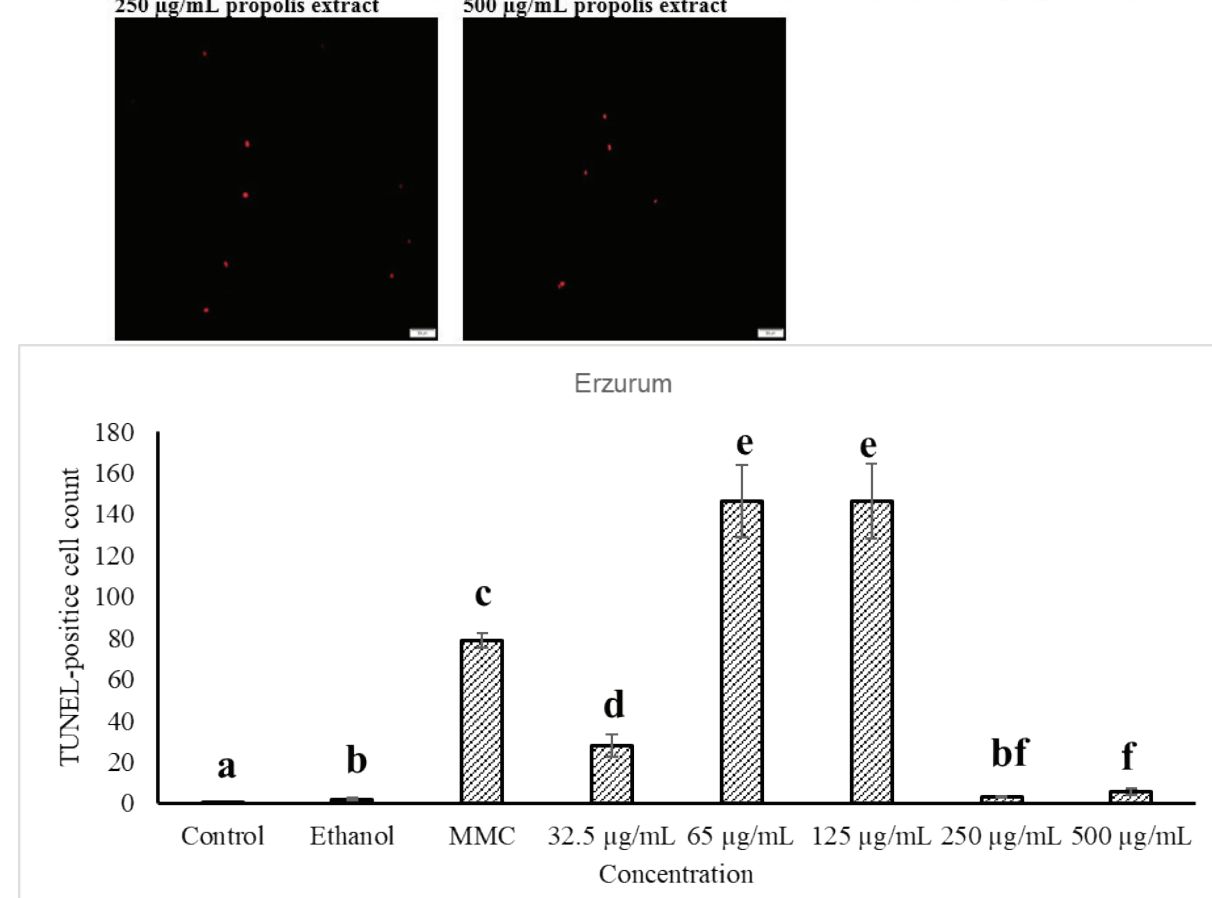

Figure 2 Apoptotic effects of $A$. m. caucasica propolis extracts from the Erzurum province of Turkey on MCF-7 cancer cells A (visualised with TUNEL, 20x magnification); B Apoptotic cell count (mean \pm standard error) (Minimum 10, maximum 35 regions were photographed and scanned for their cell number). Columns marked with different letters denote significant difference $(P<0.05)$. MMC - mitomycin C

Table 10 Minimal inhibition concentrations of the ethanolic extracts of $A . m$. caucasica propolis samples from the Ardahan and Erzurum provinces of Turkey

\begin{tabular}{lcc}
\hline Microorganism & Ardahan $(\boldsymbol{\mu g} / \mathbf{m L})$ & Erzurum $(\boldsymbol{\mu g} / \mathbf{m L})$ \\
\hline Klebsiella pneumoniae & 30.71 & 43.37 \\
\hline Staphylococcus aureus ATCC 6538 & 30.71 & 43.37 \\
\hline Bacillus megaterium DSM 32 & 30.71 & 43.37 \\
\hline
\end{tabular}


provinces (79). The latter report suggests that lower propolis concentrations seem to trigger the extrinsic apoptotic pathway by inducing caspase- 8 activity, while higher concentrations cause necrotic death, which cannot be detected by the TUNEL assay. Similarly, Szliszka and Krol (80) suggest that flavonoid and phenolic components in propolis cause apoptosis in cancer cells by increasing the TNF-related apoptosis-inducing ligand (TRAIL) activity, which is associated with caspase- 8 activity. Another study (81) showed that caffeic acid phenethyl ester in propolis can trigger the extrinsic apoptotic pathway by inducing TRAIL activity in human hepatocellular carcinoma cells. There is also evidence that cinnamic acid derivatives found in propolis, such as artepillin $\mathrm{C}$, baccharin, and drupanin, induced both extrinsic and intrinsic apoptotic death in human colon cancer cells (82).

Considering, however, that the TUNEL assay can only determine apoptotic cells, further mechanistic studies should determine the fate of cells exposed to propolis concentrations higher than $125 \mu \mathrm{g} / \mathrm{mL}$, test our assumption of a necrosis pathway, and give a more comprehensive idea about the anticarcinogenic effects of propolis.

Tables 9 and 10 show that the Ardahan propolis was more potent against $K$. pneumoniae, $S$. aureus, and $B$. megaterium DSM 32 than the Erzurum propolis, but neither was effective against $P$. aeruginos $a$ or the fungi $C$. albicans and $Y$. lipolytica. The higher antibacterial activity of the Ardahan propolis is probably related to its higher sugar content (83). Antimicrobial activity of propolis is also associated with its phenolic, flavonoid, and ester content, according to some reports $(84,85)$, which may explain the difference in antibacterial activity between the Ardahan and Erzurum propolis samples in our study but not the absence of antifungal effect in either, even though one Brazilian (86) and one Turkish study (87) reported a significant antifungal effect. One study from Chile (88) showed different phenolic/flavonoid content and antimicrobial activities of propolis from six locations but found no clear correlation between the two.

In conclusion, our findings confirm that geographical differences are important for the chemical composition of propolis and the related biological activity. Both the Ardahan and Erzurum propolis samples were produced by the same Caucasian bee race yet showed different fatty acid, phenolic, flavonoid, and other organic content. Higher sugar, flavonoid, and phenolic content of the Ardahan propolis may have contributed to its higher antioxidant and antibacterial properties. In turn, the Erzurum propolis showed higher anticarcinogenic potential, but this aspect requires further investigation to include the cell necrosis pathway.

\section{Acknowledgements}

We would like to thank the Adiyaman University Central Research Laboratory Application and Research Centre and the Aksaray University Scientific and Technological Application and Research Centre for their technical support. We would also like to thank our healthy blood donors for cytotoxicity tests. This project was supported by the Turkish Scientific and Technical Research Council (TUBITAK) (project no. 116Z049).

\section{Conflict of interests}

None to declare.

\section{REFERENCES}

1. Uzel A, Sorkun K, Onçağ O, Çoğulu D, Gençay O, Salih B. Chemical compositions and antimicrobial activities of four different Anatolian propolis samples. Microbiol Res 2005;160:189-95. doi: 10.1016/j.micres.2005.01.002

2. Nina N, Lima B, Feresin GE, GimenezA, Salamanca Capusiri E, Schmeda-Hirschmann G. Antibacterial and leishmanicidal activity of Bolivian propolis. Let Appl Microbiol 2016;62:290-6. doi: 10.1111/lam.12543

3. Kitamura H, Saito N, Fujimoto J, Nakashima K-I, Fujikura D. Brazilian propolis ethanol extract and its component kaempferol induce myeloid- derived suppressor cells from macrophages of mice in vivo and in vitro. BMC Complement Altern Med 2018;18:138. doi: 10.1186/s12906-018-2198-5

4. Degirmencioglu HT, Guzelmeric E, Yuksel PI, Kırmızıbekmez H, Deniz I, Yesilada E. A new type of Anatolian propolis: Evaluation of its chemical composition, activity profile and botanical origin. Chem Biodivers 2019;16(12):e1900492. doi: 10.1002/cbdv.201900492

5. Braik A, Lahouel M, Merabet R, Djebar MR, Morin D. Myocardial protection by propolis during prolonged hypothermic preservation. Cryobiology 2019;88:29-37. doi: 10.1016/j.cryobiol.2019.04.003

6. Geyikoglu F, Koc K, Colak S, Erol HS, Cerig S, Yardimci BK, Cakmak O, Dortbudak MB, Eser G, Aysin F, Ozek NS, Yildirim S. Propolis and its combination with boric acid protect against ischemia/reperfusion-induced acute kidney injury by inhibiting oxidative stress, inflammation, DNA damage, and apoptosis in rats. Biol Trace Elem Res 2019;192:214-21. doi: 10.1007/s12011-019-1649-2

7. González-Búrquez M de J, González-Díaz FR, García-Tovar CG, Carrillo-Miranda L, Soto-Zárate CI, Canales-Martínez MM, Penieres-Carrillo JG, Crúz-Sánchez TA, FonsecaCoronado S. Comparison between in vitro antiviral effect of Mexican propolis and three commercial flavonoids against canine distemper virus. Evid-Based Complement Altern Med 2018;2018:7092416. doi: 10.1155/2018/7092416

8. Seyhan MF, Y1lmaz E, Timirci-Kahraman Ö, Sayg1lı N, Kısakesen Hİ, Gazioğlu S, Gören AC, Pınar Eronat A, Begüm Ceviz A, Öztürk T, Y1lmaz-Aydoğan H, Öztürk O. Different propolis samples, phenolic content, and breast cancer cell lines: Variable cytotoxicity ranging from ineffective to potent. IUBMB Life 2019;71:619-31. doi: 10.1002/iub.1996

9. Castaldo S, Capasso F. Propolis, an old remedy used in modern medicine. Fitoterapia 2002;73(Suppl 1):S1-6. doi: 10.1016/S0367-326X(02)00185-5

10. Kujumgiev A, Tsvetkova I, Serkedjieva Y, Bankova V, Christov R, Popov S. Antibacterial, antifungal and antiviral activity of propolis of different geographic origin. J 
Ethnopharmacol 1999;64:235-40. doi: 10.1016/S03788741(98)00131-7

11. Machado BAS, Silva RPD, Barreto G de A, Costa SS, da Silva DF, Brandão HN, Carneiro da Rocha JL, Dellagostin OA, Pegas Henriques JA, Umsza-Guez MA, Padilha FF. Chemical composition and biological activity of extracts obtained by supercritical extraction and ethanolic extraction of brown, green and red propolis derived from different geographic regions in Brazil. PLoS One 2016;11(1):e0145954. doi: 10.1371/journal.pone.0145954

12. Keskin M, Kolayli S. Propoliste standardizasyon mümkün mü? [Standardization of propolis, is it possible?, in Turkish] Uludağ Arıc1lık Derg 2018;18:101-10. doi: 10.31467/ uluaricilik. 485080

13. Marcucci MC. Propolis: chemical composition, biological properties and therapeutic activity. Apidologie 1995;26:8399. doi: 10.1051/apido:19950202

14. Bogdanov S. Contaminants of bee products. Apidologie 2006;37:1-18. doi: 10.1051/apido:2005043

15. Cengiz MM, Erdoğan Y. Comparison of wintering ability and colony performances of different honeybee (Apis mellifera L.) genotypes in Eastern Anatolian/Turkey conditions. Kafkas Üniv Vet Fak Derg 2017;23:865-70. doi: $10.9775 / \mathrm{kvfd} .2017 .17667$

16. Genç F, Dülger C, Dodoloğlu A, Kutluca S. Comparison of some physiological characters of Caucasian, Central Anatolian and Erzurum honeybee (Apis mellifera L.) genotypes in the conditions of Erzurum. Turk J Vet Anim Sci 1999;23:645-50

17. Silici S, Kutluca S. Chemical composition and antibacterial activity of propolis collected by three different races of honeybees in the same region. J Ethnopharmacol 2005;99:6973. doi: $10.1016 /$ j.jep.2005.01.046

18. Trusheva B, Trunkova D, Bankova V. Different extraction methods of biologically active components from propolis: a preliminary study. Chem Cent J 2007;1:13. doi: 10.1186/1752153X-1-13

19. Barbosa RA, Nunes TLGM, Nunes TLGM, da Paixão AO, Neto RB, Moura S, Cavalcanti Albuquerque Junior RL, Farias Cândido EA, Padilha FF, Quintans-Júnior LJ, Gomes MZ, Cardoso JC. Hydroalcoholic extract of red propolis promotes functional recovery and axon repair after sciatic nerve injury in rats. Pharm Biol 2016;54:993-1004. doi: 10.3109/13880209.2015.1091844

20. Ugur A, Arslan T. An in vitro study on antimicrobial activity of propolis from Mugla province of Turkey. J Med Food 2004;7:90-4. doi: 10.1089/109662004322984761

21. Cvek J, Medić-Šarić M, Vitali D, Vedrina-Dragojević I, Šmit Z, Tomić S. The content of essential and toxic elements in Croatian propolis samples and their tinctures. J Apic Res 2008;47:35-45. doi: 10.1080/00218839.2008.11101421

22. Korn MGA, Guida MAB, Barbosa JTP, Torres EA, Fernandes AP, Santos JCC, Dantas KGF, Nóbrega JA. Evaluation of sample preparation procedures for trace element determination in Brazilian propolis by inductively coupled plasma optical emission spectrometry and their discrimination according to geographic region. Food Anal Methods 2013;6:872-80. doi: 10.1007/s12161-012-9497-0

23. Hara A, Radin NS. Lipid extraction of tissues with a lowtoxicity solvent. Anal Biochem 1978;90:420-6. doi: 10.1016/0003-2697(78)90046-5
24. Christie WW. The preparation of alkyl esters from fatty acids and lipids. In: Gunston FD, editor. Topics in lipid chemistry. Vol. 3. London: Paul Elek (Scientific Books) Ltd.; 1972. p. 171-97.

25. Proestos C, Komaitis M. Analysis of naturally occurring phenolic compounds in aromatic plants by RP-HPLC coupled to diode array detector (DAD) and GC-MS after silylation. Foods 2013;2:90-9. doi: 10.3390/foods2010090

26. Meda A, Lamien CE, Romito M, Millogo J, Nacoulma OG. Determination of the total phenolic, flavonoid and proline contents in Burkina Fasan honey, as well as their radical scavenging activity. Food Chem 2005;91:571-7. doi: 10.1016/j.foodchem.2004.10.006

27. Chang CC, Yang MH, Wen HM, Chern JC. Estimation of total flavonoid content in propolis by two complementary colorimetric methods. J Food Drug Anal 2002;10:178-82. doi: $10.38212 / 2224-6614.2748$

28. Köksal E, Gülçin İ. Antioxidant activity of cauliflower (Brassica oleracea L.). Turk J Agric For 2008;32:65-78.

29. Molyneux P. The use of the stable radical diphenylpicrylhydrazyl (DPPH) for estimating antioxidant activity. Songklanakarin J Sci Technol 2004;26:211-9.

30. Benzie IF, Strain JJ. The ferric reducing ability of plasma (FRAP) as a measure of "antioxidant power": the FRAP assay. Anal Biochem 1996;239:70-6. doi: 10.1006/ abio.1996.0292

31. Kocaman AY, Topaktaş M. In vitro evaluation of the genotoxicity of acetamiprid in human peripheral blood lymphocytes. Environ Mol Mutagen 2007;48:483-90. doi: 10.1002/em.20309

32. Berridge MV, Tan AS. Characterization of the cellular reduction of 3-(4,5-dimethylthiazol-2-yl)-2,5diphenyltetrazolium bromide (MTT): subcellular localization, substrate dependence, and involvement of mitochondrial electron transport in MTT reduction. Arch Biochem Biophys 1993;303:474-82. doi: 10.1006/abbi.1993.1311

33. Cheki M, Shirazi A, Mahmoudzadeh A, Bazzaz JT, Hosseinimehr SJ. The radioprotective effect of metformin against cytotoxicity and genotoxicity induced by ionizing radiation in cultured human blood lymphocytes. Mutat Res 2016;809:24-32. doi: 10.1016/j.mrgentox.2016.09.001

34. Jain SK. Evidence for membrane lipid peroxidation during the in vivo aging of human erythrocytes. Biochim Biophys Acta 1988;937:205-10. doi: 10.1016/0005-2736(88)90242-8

35. Do TQ, Schultz JR, Clarke CF. Enhanced sensitivity of ubiquinone-deficient mutants of Saccharomyces cerevisiae to products of autoxidized polyunsaturated fatty acids. Proc Natl Acad Sci USA 1996;93:7534-9. doi: 10.1073/ pnas.93.15.7534

36. Stoscheck CM. Quantitation of protein. Methods Enzymol 1990;182:50-68. doi: 10.1016/0076-6879(90)82008-P

37. Collins CH, Lyne PM, Grange JM. Collins and Lynes Microbiological Methods. $7^{\text {th }}$ ed. Oxford: ButterworthHeinman Ltd.; 1995.

38. Abbasoğlu U, Tosun F, Aydınoğlu A. Antimicrobial activity of Gonocytisus angulus (L.) Spach. FABAD J Pharm Sci 1995;20:125-7.

39. Erbil N, Arslan M, Murathan ZT, Ilcim A, Borekci BS. Some biological effects of the fruits and leaves of different apple cultivars, including red-fleshed apples, grown in a microclimatic region of Turkey: Part I. Erwerbs-Obstbau 2020;62:399-410. doi: 10.1007/s10341-020-00527-5 
40. Duman R, Uysal NE, Aladağ MO. Evaluation of antibacterial activities of Taraxacum farinosum Hausskn. Et Bornm and Taraxacum mirabile Wagenitz extracts. Int J Sci Technol Res 2016;2:46-54.

41. Bonvehí JS, Bermejo FJO. Element content of propolis collected from different areas of South Spain. Environ Monit Assess 2013;185:6035-47. doi: 10.1007/s10661-012-3004-3

42. Formicki G, Greń A, Stawarz R, Zyśk B, Gal A. Metal content in honey, propolis, wax, and bee pollen and implications for metal pollution monitoring. Pol J Environ Stud 2013;22:99106.

43. Dogan M, Silici S, Saraymen R, Ilhan IO. Element content of propolis from different regions of Turkey. Acta Aliment 2006;35:127-30. doi: 10.1556/aalim.35.2006.1.14

44. Aksoy C, Atabay MM, Tirasoglu E, Koparan ET, Kekillioglu A. Elemental content profiles in propolis from several cities of Turkey. Funct Foods Health Dis 2017;7:661-70. doi: 10.31989/ffhd.v7i8.358

45. World Health Organization (WHO). Trace elements in human nutrition and health, 1996 [displayed 6 November 2020]. Available at http://www.who.int/nutrition/publications/ micronutrients/9241561734/en/

46. Sahinler N, Kaftanoglu O. Natural product propolis: chemical composition. Nat Prod Res 2005;19:183-8. doi: 10.1080/14786410410001704877

47. Rebiai A, Belfar ML, Mesbahi MA, Nani S, Tliba A, Amara DG. Fatty acid composition of Algerian propolis. J Fundam Appl Sci 2017;9:1656-71. doi: 10.4314/jfas.v9i3.26

48. Negri G, Marcucci C, Salatino A, Salatino MLF. Comb and propolis waxes from Brazil (states of São Paulo and Paraná). J Braz Chem Soc 2000;11:453-7. doi: 10.1590/S010350532000000500004

49. Markham KR, Mitchell KA, Wilkins AL, Daldy JA, Lu Y. HPLC and GC-MS identification of the major organic constituents in New Zeland propolis. Phytochemistry 1996;42:205-11. doi: 10.1016/0031-9422(96)83286-9

50. Shakya AK, Katekhaye S, Oriquat GA, Naik RR, Naik RR, Paradkar A, Fearnely H, Fearnely J. Fatty acid analysis and biological activity of Jordanian propolis. Apiterapi Doğa Derg 2018;1(3):33.

51. Duca A, Alexa E, Dehelean CA, Soica C, Danciu C, Popescu I, Cocan I, Lalescu D, Muntean D. Assessment of lipid profile of eight propolis samples from Western Romania. Farmacia 2019;67:126-32. doi: 10.31925/farmacia.2019.1.17

52. Custodio AR, Ferreira MMC, Negri G, Salatino A. Clustering of comb and propolis waxes based on the distribution of aliphatic constituents. J Braz Chem Soc 2003;14:354-7. doi: 10.1590/S0103-50532003000300003

53. Ramnath S, Venkataramegowda S, Singh C. Chemical composition of bee propolis collected from different regions in India by GC-MS analysis. Int J Pharmacognosy Phytochem 2015;30:1319-28.

54. Christov R, Bankova V, Hegazi A, Hady FAE, Popov S. Chemical composition of Egyptian propolis. Z Naturforsch C 1998;53:197-200. doi: 10.1515/znc-1998-3-409

55. Bankova VS, Christov R, Tejera AD. Lignans and other constituents of propolis from the Canary Islands. Phytochemistry 1998;49:1411-5. doi: 10.1016/S00319422(98)00108-3

56. Greenaway W, Scaysbrook T, Whatley FR. Composition of propolis in Oxfordshire, U.K. and its relation to poplar bud exudate. Z Naturforsch C 1988;43:301-5. doi: 10.1515/znc1988-3-423

57. García-Viguera C, Ferreres F, Tomás-Barberán FA. Study of Canadian propolis by GC-MS and HPLC. Z Naturforsch C 1993;48:731-5. doi: 10.1515/znc-1993-9-1009

58. Gülçin I, Bursal E, Sehitoğlu MH, Bilsel M, Gören AC. Polyphenol contents and antioxidant activity of lyophilized aqueous extract of propolis from Erzurum, Turkey. Food Chem Toxicol 2010;48:2227-38. doi: 10.1016/j. fct.2010.05.053

59. Al-Ani I, Zimmermann S, Reichling J, Wink M. Antimicrobial activities of European propolis collected from various geographic origins alone and in combination with antibiotics. Medicines (Basel) 2018;5:1-17. doi: 10.3390/ medicines 5010002

60. Greenaway W, Gümüsdere I, Whatley FR. Analysis of phenolics of bud exudate of Populus euphratica by GC-MS. Phytochemistry 1991;30:1883-5. doi: 10.1016/00319422(91)85032-U

61. Popova M, Silici S, Kaftanoglu O, Bankova V. Antibacterial activity of Turkish propolis and its qualitative and quantitative chemical composition. Phytomedicine 2005;12:221-8. doi: 10.1016/j.phymed.2003.09.007

62. Velikova M, Bankova V, Sorkun K, Houcine S, Tsvetkova I, Kujumgiev A. Propolis from the Mediterranean region: chemical composition and antimicrobial activity. Z Naturforsch C 2000;55:790-3. doi: 10.1515/znc-2000-91019

63. Ozdal T, Ceylan FD, Eroglu N, Kaplan M, Olgun EO, Capanoglu E. Investigation of antioxidant capacity, bioaccessibility and LC-MS/MS phenolic profile of Turkish propolis. Food Res Int 2019;122:528-36. doi: 10.1016/j. foodres.2019.05.028

64. Lagouri V, Prasianaki D, Krysta III F. Antioxidant properties and phenolic composition of Greek propolis extracts. Int $\mathrm{J}$ Food Prop 2014;17:511-22. doi : 10.1080/10942912.2012.654561

65. Moreno MI, Isla MI, Sampietro AR, Vattuone MA. Comparison of the free radical-scavenging activity of propolis from several regions of Argentina. J Ethnopharmacol 2000;71:109-14. doi: 10.1016/S0378-8741(99)00189-0

66. Sime D, Atlabachew M, Abshiro MR, Zewde T. Total phenols and antioxidant activities of natural honeys and propolis collected from different geographical regions of Ethiopia. Bull Chem Soc Ethiop 2015;29:163-72. doi: 10.4314/bcse. v29i2.1

67. Bankova V, Dyulgerov A, Popov S, Evstatieva L, Kuleva L, Pureb O, Zamjansan Z. Propolis produced in Bulgaria and Mongolia: phenolic compounds and plant origin. Apidologie 1992;23:79-85. doi: 10.1051/apido:19920109

68. Barlak Y, Değer O, Çolak M, Karataylı SC, Bozdayı AM, Yücesan F. Effect of Turkish propolis extracts on proteome of prostate cancer cell line. Proteome Sci 2011;9:1-11. doi: 10.1186/1477-5956-9-74

69. Paolini A, Curti V, Pasi F, Mazzini G, Nano R, Capelli E. Gallic acid exerts a protective or an anti-proliferative effect on glioma T98G cells via dose-dependent epigenetic regulation mediated by miRNAs. Int J Oncol 2015;46:149197. doi: 10.3892/ijo.2015.2864

70. Paz MM, Zhang X, Lu J, Holmgren A. A new mechanism of action for the anticancer drug mitomycin C: Mechanism- 
based inhibition of thioredoxin reductase. Chem Res Toxicol 2012;25:1502-11. doi: 10.1021/tx3002065

71. An Q, Han C, Zhou Y, Li F, Li D, Zhang X, Yu Z, Duan Z, Kan Q. In vitro effects of mitomycin $\mathrm{C}$ on the proliferation of the non-small-cell lung cancer line A549. Int J Clin Exp Med 2015;8:20516-23. PMID: 26884968

72. Nakajima Y, Shimazawa M, Mishima S, Hara H. Water extract of propolis and its main constituents, caffeoylquinic acid derivatives, exert neuroprotective effects via antioxidant actions. Life Sci 2007;80:370-7. doi: 10.1016/j. lfs.2006.09.017

73. Xu BH, Gupta V, Singh SV. Mechanism of differential sensitivity of human bladder cancer cells to mitomycin C and its analogue. Br J Cancer 1994;69:242-6. doi: 10.1038/ bjc. 1994.46

74. Ortega-Gutiérrez S, López-Vicente M, Lostalé F, FuentesBroto L, Martínez-Ballarín E, García JJ. Protective effect of melatonin against mitomycin $\mathrm{C}$-induced genotoxic damage in peripheral blood of rats. J Biomed Biotechnol 2009;2009:791432. doi: 10.1155/2009/791432

75. Sobocanec S, Sverko V, Balog T, Sarić A, Rusak G, Likić S, Kusić B, Katalinić V, Radić S, Marotti T. Oxidant/antioxidant properties of Croatian native propolis. J Agric Food Chem 2006;54:8018-26. doi: 10.1021/jf0612023

76. Rietjens IMCM, Boersma MG, Haan L de, Spenkelink B, Awad HM, Cnubben NHP, van Zanden JJ, van der Woude H, Alink GM, Koeman JH. The pro-oxidant chemistry of the natural antioxidants vitamin $\mathrm{C}$, vitamin $\mathrm{E}$, carotenoids and flavonoids. Environ Toxicol Pharmacol 2002;11:321-33. doi: 10.1016/S1382-6689(02)00003-0

77. Tsai YC, Wang YH, Liou CC, Lin YC, Huang H, Liu YC. Induction of oxidative DNA damage by flavonoids of propolis: its mechanism and implication about antioxidant capacity. Chem Res Toxicol 2012;25:191-6. doi: 10.1021/ tx200418k

78. Kusuma ID, Rosidah A, Norahmawati E, Nurdiana N, Endharti AT. Indonesian Pasuruan propolis extract does not exert antiproliferation and pro-apoptotic effect on human colon carcinoma cell line HT-29. Trop J Pharm Res 2018;17:1345-51. doi: 10.4314/tjpr.v17i7.17

79. Seda Vatansever H, Sorkun K, İsmet Deliloğlu Gurhan S, Ozdal-Kurt F, Turkoz E, Gencay O, Salih B. Propolis from Turkey induces apoptosis through activating caspases in human breast carcinoma cell lines. Acta Histochem 2010;112:546-56. doi: 10.1016/j.acthis.2009.06.001

80. Szliszka E, Krol W. Polyphenols isolated from propolis augment TRAIL-induced apoptosis in cancer cells. Evid Based Complement Alternat Med 2013;2013:e731940. doi: 10.1155/2013/73194

81. Kim EY, Ryu J-H, Kim AK. CAPE promotes TRAIL-induced apoptosis through the upregulation of TRAIL receptors via activation of p38 and suppression of JNK in SK-Hep1 hepatocellular carcinoma cells. Int J Oncol 2013;43:1291300. doi: 10.3892/ijo.2013.2018

82. Kumazaki M, Shinohara H, Taniguchi K, Yamada N, Ohta $\mathrm{S}$, Ichihara K, Akao Y. Propolis cinnamic acid derivatives induce apoptosis through both extrinsic and intrinsic apoptosis signaling pathways and modulate of miRNA expression. Phytomedicine 2014;21:1070-7. doi: 10.1016/j. phymed.2014.04.006

83. Kwakman PHS, Zaat SAJ. Antibacterial components of honey. IUBMB Life 2012;64:48-55. doi: 10.1002/iub.578

84. Ghisalberti EL. Propolis: a review. Bee World 1979;60:5984. doi: 10.1080/0005772X.1979.11097738

85. Mirzoeva OK, Grishanin RN, Calder PC. Antimicrobial action of propolis and some of its components: the effects on growth, membrane potential and motility of bacteria. Microbiol Res 1997;152:239-46. doi: 10.1016/S09445013(97)80034-1

86. Correa FT, de Souza AC, de Souza Júnior EA, Isidoro SR, Piccoli RH, Dias DR, de Abreu LR. Effect of Brazilian green propolis on microorganism contaminants of surface of Gorgonzola-type cheese. J Food Sci Technol 2019;56:197887. doi: 10.1007/s13197-019-03664-2

87. Mutlu Sariguzel F, Berk E, Koc AN, Sav H, Demir G. Antifungal activity of propolis against yeasts isolated from blood culture: In vitro evaluation. J Clin Lab Anal 2016;30:513-6. doi: 10.1002/jcla.21889

88. Bridi R, Montenegro G, Nuñez-Quijada G, Giordano A, Fernanda Morán-Romero M, Jara-Pezoa I, Speisky H, Atala E, López-Alarcón C. International regulations of propolis quality: required assays do not necessarily reflect their polyphenolic-related in vitro activities. J Food Sci 2015;80:C1188-95. doi: 10.1111/1750-3841.12881 


\section{Usporedba kemijskih i bioloških značajki propolisa pčelinje pasmine Apis mellifera caucasica iz turskih provincija} Ardahana i Erzuruma

Cilj je ovoga istraživanja bio usporediti biološku aktivnost etanolnih ekstrakata propolisa pčelinje pasmine Apis mellifera caucasica iz dviju turskih provincija: Ardahana i Erzuruma. Testirana su njihova antioksidacijska, anticitotoksična, antikancerogena, antibakterijska i antifungalna svojstva. Uzorci iz tih dviju provincija razlikovali su se u mineralnom i organskom sastavu koji je odražavao njihovo zemljopisno podrijetlo. Test redukcije željeza/antioksidacijske snage (engl. ferric reducing antioxidant power, krat. FRAP) otkrio je superiornost ardahanskoga propolisa nad erzurumskim, no bez obzira na podrijetlo i prisutnost mitomicina $\mathrm{C}$ u mediju, oba su propolisa povećala vijabilnost ljudskih perifernih limfocita, a učinak je ovisio o koncentraciji i trajanju. Propolis iz Erzuruma iskazao je najveću antikancerogenu aktivnost u koncentracijama od 62,5 i $125 \mu \mathrm{g} / \mathrm{mL}$, no ona se smanjila s višim koncentracijama. Oba su propolisa također iskazala antibakterijsku aktivnost sličnu ampicilinskoj i penicilinskoj kontroli, osim kad se radilo o bakteriji Pseudomonas aeruginosa. Međutim, oba su zakazala protiv plijesni Candida albicans i Yarrowia lipolytica. Može se zaključiti da uzorci propolisa iz obiju provincija pružaju obećavajuće biološke aktivnosti, no u daljnja istraživanja, koja se trebaju usmjeriti na traženje optimalnih koncentracija za postizanje željenog učinka, treba uključiti i nekrotični put u mehanizmu djelovanja kako bi se stekao bolji uvid u njihovo antikancerogeno djelovanje.

KLJUČNE RIJEČI: antikancerogeno djelovanje; antimikrobno djelovanje; biološka aktivnost; minerali; mitomicin C; organski sastav 